\title{
Aircraft and ground-based measurements of hydroperoxides during the 2006 MILAGRO field campaign
}

\author{
L. J. Nunnermacker ${ }^{1}$, J. B. Weinstein-Lloyd ${ }^{2}$, B. Hillery ${ }^{2}$, B. Giebel ${ }^{3}$, L. I. Kleinman ${ }^{1}$, S. R. Springston ${ }^{1}$, P. H. Daum ${ }^{1}$, \\ J. Gaffney ${ }^{4}$, N. Marley ${ }^{4}$, and G. Huey ${ }^{5}$ \\ ${ }^{1}$ Brookhaven National Laboratory Atmospheric Sciences Division Upton, NY 11973, USA \\ ${ }^{2}$ Chemistry/Physics Department State, University of New York, Old Westbury, NY, USA \\ ${ }^{3}$ Rosenstiel School of Marine and Atmospheric Science, Division of Marine and Atmospheric Chemistry, \\ University of Miami, Miami, FL, USA \\ ${ }^{4}$ University of Arkansas, Department of Chemistry, Little Rock, AR, USA \\ ${ }^{5}$ Georgia Institute of Technology School of Earth and Atmospheric Sciences, Atlanta, GA, USA
}

Received: 12 February 2008 - Published in Atmos. Chem. Phys. Discuss.: 20 May 2008

Revised: 7 October 2008 - Accepted: 7 October 2008 - Published: 18 December 2008

\begin{abstract}
Mixing ratios of hydrogen peroxide and hydroxymethyl hydroperoxide were determined aboard the US Department of Energy G-1 Research Aircraft during the March, 2006 MILAGRO field campaign in Mexico. Ground measurements of total hydroperoxide were made at Tecámac University, about $35 \mathrm{~km} \mathrm{NW}$ of Mexico City. In the air and on the ground, peroxide mixing ratios near the source region were generally near $1 \mathrm{ppbv}$. Strong southerly flow resulted in transport of pollutants from Mexico City to two downwind surface sites on several flight days. On these days, it was observed that peroxide concentrations slightly decreased as the G-1 flew progressively downwind. This observation is consistent with low or negative net peroxide production rates calculated for the source region and is due to the very high $\mathrm{NO}_{\mathrm{x}}$ concentrations in the Mexico City plateau. However, relatively high values of peroxide were observed at takeoff and landing near Veracruz, a site with much higher humidity and lower $\mathrm{NO}_{\mathrm{x}}$ concentrations.
\end{abstract}

\section{Introduction}

In March 2006, MILAGRO (Megacity Initiative: Local and Global Research Observations), an international and multiagency field experiment, took place with the primary goal of learning how a megacity affects air quality. Air pollution generated by megacities (i.e. population $>10$ million) is an

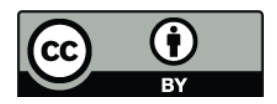

Correspondence to: L. J. Nunnermacker (lindan@bnl.gov) important environmental, health, and financial issue (Molina and Molina, 2002). In addition to local effects, there is a potential for the growing number of megacities to have global impacts on air quality as well as climate change. Mexico City is uniquely situated on an elevated basin (2240 $\mathrm{m}$ m.s.l.) surrounded by mountains with openings to the north and south-southwest. This large city has diverse sources of fossil fuel combustion, including automotive (nearly 4 million vehicles), residential cooking and heating, and various industries providing ample amounts of hydrocarbons and oxides of nitrogen.

The Department of Energy (DOE) portion of MILAGRO, the Megacity Aerosol eXperiment - MEXico City (MAXMex) focused on the chemical, physical, and optical characterization of aerosols, as well as trace gas precursors of aerosols, and photochemistry. The DOE G-1 aircraft flew in and around the city source region (MCMA=Mexico City Metropolitan Area) and into the outflow from the city in an effort to study the effects of the megacity plume. The field program was designed so that investigators could follow the outflow of the source region (T0 site - Mexican Petroleum Institute, an urban site in the northwestern part of the MCMA) as it moved over two downwind sites (T1 Tecámac University $\sim 35 \mathrm{~km}$ from T0, and T2 - Rancho la Bisnaga $\sim 70 \mathrm{~km}$ from T0) (Doran et al., 2007).

Peroxides are important termination products of the freeradical chemistry responsible for ozone formation in the troposphere. Under low $\mathrm{NO}_{\mathrm{x}}$ (nitric oxide and nitrogen dioxide; $\left.\left[\mathrm{NO}+\mathrm{NO}_{2}\right]\right)$ conditions, combination reactions of peroxy radicals $\left(\mathrm{HO}_{2}\right.$ and $\left.\mathrm{RO}_{2}\right)$ leading to hydroperoxides $\left(\mathrm{H}_{2} \mathrm{O}_{2}\right.$ and $\left.\mathrm{ROOH}\right)$ are the primary termination pathway for

Published by Copernicus Publications on behalf of the European Geosciences Union. 
Table 1. Flights when the peroxide instrument was operational.

\begin{tabular}{llll}
\hline Flight & $\begin{array}{l}\text { Start time } \\
\text { (LST) }\end{array}$ & $\begin{array}{l}\text { Stop time } \\
\text { (LST) }\end{array}$ & General description \\
\hline 060315b & $15: 00: 41$ & $18: 15: 36$ & Weak Southeasterly flow \\
060318a & $13: 28: 32$ & $17: 09: 50$ & Southerly flow No a.m. flight \\
060319a & $09: 58: 40$ & $12: 52: 41$ & Strong South-Southwesterly flow \\
060319b & $14: 55: 38$ & $18: 05: 04$ & Strong Southwesterly flow \\
060320a & $09: 32: 50$ & $12: 17: 22$ & Strong South-Southwesterly flow \\
060320b & $14: 01: 49$ & $16: 58: 15$ & Strong Southwesterly flow \\
060322a & $09: 30: 46$ & $12: 23: 30$ & Moderate Southwesterly flow No p.m. flight \\
060326a & $09: 46: 34$ & $12: 58: 30$ & Weak Westerly to Southwesterly flow No p.m. flight \\
060327a & $10: 57: 37$ & $14: 09: 50$ & Weak Southerly flow No p.m. flight \\
\hline
\end{tabular}

the ozone $\left(\mathrm{O}_{3}\right)$ forming chain reaction. Under high $\mathrm{NO}_{\mathrm{x}}$ conditions, concentrations of $\mathrm{HO}_{2}$ and $\mathrm{RO}_{2}$ are suppressed by reactions with NO. The primary termination pathway is then by reaction of free radicals with $\mathrm{NO}_{\mathrm{x}}$, leading to compounds collectively designated as $\mathrm{NO}_{\mathrm{z}}$, which include nitric acid $\left(\mathrm{HNO}_{3}\right)$, organic nitrates, and peroxyacetyl nitrates. Photochemical model calculations show that ozone production is $\mathrm{NO}_{\mathrm{x}}$ - or VOC-limited according to whether it occurs under low or high $\mathrm{NO}_{\mathrm{x}}$ conditions, or equivalently according to whether hydrogen peroxide or $\mathrm{HNO}_{3}$ (sometimes approximated by $\mathrm{NO}_{\mathrm{z}}$ ) is the primary termination product (Sillman, 1995; Kleinman, 2001, 2005a). The ratio of $\mathrm{H}_{2} \mathrm{O}_{2}$ to $\mathrm{HNO}_{3}$ therefore indicates whether $\mathrm{O}_{3}$ was formed in a $\mathrm{NO}_{\mathrm{x}}-$ or VOC-limited environment and can be used to develop $\mathrm{O}_{3}$ mitigation strategies (Sillman, 1995, 1999; Watkins et al., 1995).

In comparison to other cities in which the G-1 has been used for urban sampling, $\mathrm{NO}_{\mathrm{x}}$ concentrations over downtown Mexico City are extremely high (Kleinman et al., 2005b). Concentrations at $500 \mathrm{~m}$ altitude (a.g.1.) approach $100 \mathrm{ppbv}$, a value usually seen only in power plant plumes. Under these conditions it is expected that peroxide formation will be suppressed and $\mathrm{O}_{3}$ production will be strongly VOC limited. Peak $\mathrm{O}_{3}$ levels, however, occur in the afternoon under lower $\mathrm{NO}_{\mathrm{x}}$ conditions in areas that are downwind of the City. The usual sequence of events is for photochemistry to start out VOC limited and become $\mathrm{NO}_{\mathrm{x}}$ limited as an air mass ages (Kleinman et al., 2001). There is little observational evidence as to where and when this transition occurs in Mexico City and how it affects peak $\mathrm{O}_{3}$ levels.

In place of direct observational evidence, models have been used to determine whether peak $\mathrm{O}_{3}$ concentrations in Mexico City can be more effectively controlled by reducing $\mathrm{NO}_{\mathrm{x}}$ or VOC emissions (Lei et al., 2007; Tie et al., 2007). Models typically are validated by their performance in pre- dicting concentrations of $\mathrm{O}_{3}$ and a few other commonly measured species. Often, such models correctly predict ozone, but fail to correctly predict concentrations of the peroxide and $\mathrm{HNO}_{3}$ radical termination products. From the standpoint of developing $\mathrm{O}_{3}$ control strategies, it is important that models properly represent the chemical pathways associated with $\mathrm{NO}_{\mathrm{x}}$ and VOC limited conditions. Accurate $\mathrm{H}_{2} \mathrm{O}_{2}$ observations and model predictions of $\mathrm{H}_{2} \mathrm{O}_{2}$ are important in distinguishing between these pathways.

The MILAGRO campaign was the first instance in which gaseous hydroperoxides were measured in Mexico City. This study presents measurements from the $\mathrm{T} 1$ surface site and the G-1 aircraft using a glass coil inlet scrubber with continuous flow derivatization and fluorescence detection (Lee et al., 1990, 1994). G-1 flights were directed primarily at measurements over Mexico City and downwind areas on the Mexico City plateau. Ferry segments to and from Veracruz, located in a more humid, less polluted environment $300 \mathrm{~km}$ to the east on the Gulf of Mexico, provide an interesting contrast to the observations taken over the plateau.

Because we sample using aqueous solution, only soluble hydroperoxides are collected. Previous studies have shown that hydrogen peroxide $\left(\mathrm{H}_{2} \mathrm{O}_{2}\right)$, methyl hydroperoxide $\left(\mathrm{CH}_{3} \mathrm{OOH}\right.$ or MHP) and hydroxymethyl hydroperoxide $\left(\mathrm{HOCH}_{2} \mathrm{OOH}\right.$ or HMHP) are the principal species observed under these conditions (Lee et al., 2000). $\mathrm{H}_{2} \mathrm{O}_{2}$ is the product of self-reaction of $\mathrm{HO}_{2}$ radicals. $\mathrm{CH}_{3} \mathrm{OOH}$ is also a radical termination product, arising from the reaction between $\mathrm{HO}_{2}$ and $\mathrm{CH}_{3} \mathrm{O}_{2}$ radicals, the latter formed from oxidation of methane by $\mathrm{OH}$ radical. While HMHP may be formed from radical-radical reactions (Qi et al., 1999), it is also formed when ozone reacts with terminal alkenes in the atmosphere (Lee et al., 2000, and references therein). The particular hydroperoxides determined during this study are described in the experimental section. 


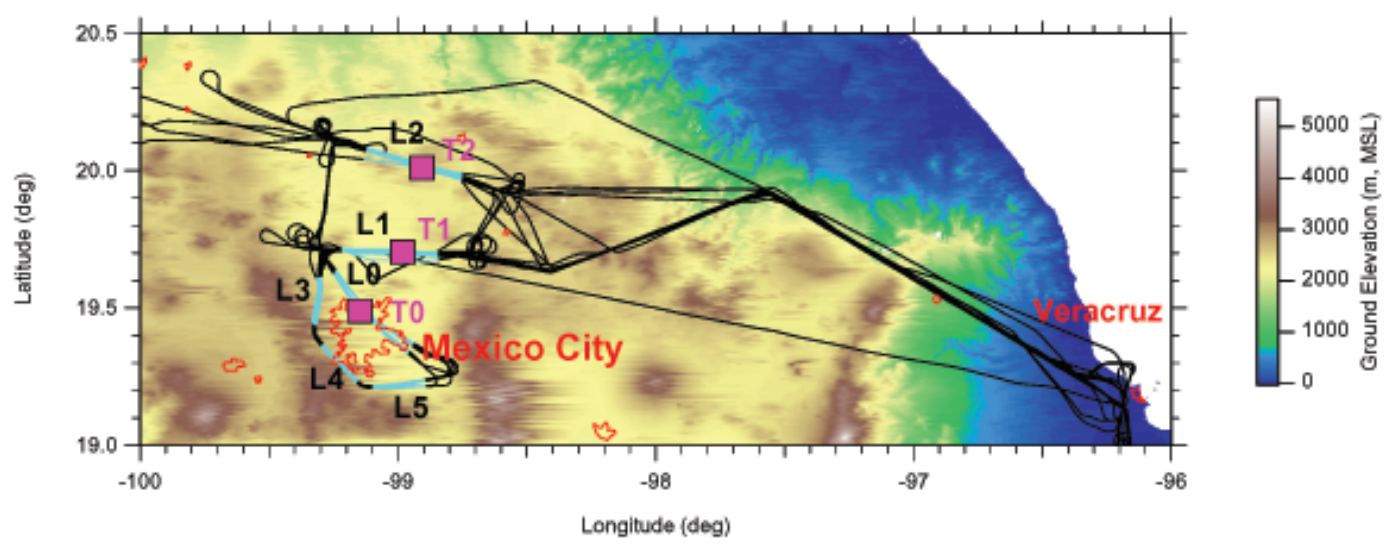

Fig. 1. Composite of all flight tracks, 15-27 March 2006. The Mexico City Metropolitan Area (MCMA) is indicated by the red outline within the flight tracks. The surface sites, T0, T1, and T2 are indicated by the red squares.

Table 2. Three channel peroxide instrument operating parameters.

\begin{tabular}{llll}
\hline Channel \# & $\begin{array}{l}\text { Scrubbing } \\
\text { solution } \\
\mathrm{pH}\end{array}$ & $\begin{array}{l}\text { Derivatizing } \\
\text { reagent }\end{array}$ & $\begin{array}{l}\text { Species } \\
\text { detected }\end{array}$ \\
\hline 1 & $\mathrm{pH} 9$ & $\begin{array}{l}\text { p-hydroxyphenylacetic } \\
\text { acid (POHPAA) }\end{array}$ & $\begin{array}{l}\text { Total soluble hydroperoxide }= \\
\left(\mathrm{H}_{2} \mathrm{O}_{2}+\mathrm{MHP}^{*}+\mathrm{HMHP}^{* *}\right)\end{array}$ \\
2 & $\mathrm{pH} 9$ & $\begin{array}{l}\text { Ferrous sulfate/ } \\
\text { benzoic acid (FeBA) }\end{array}$ & $\mathrm{H}_{2} \mathrm{O}_{2}+\mathrm{HMHP}$ \\
3 & $\mathrm{pH} \mathrm{6}$ & $\begin{array}{l}\text { Ferrous sulfate/ } \\
\text { benzoic acid (FeBA) }\end{array}$ & $\mathrm{H}_{2} \mathrm{O}_{2}$ \\
\hline
\end{tabular}

*Methyl hydroperoxide **Hydroxymethyl hydroperoxide

\section{Experimental}

\subsection{Meteorological conditions and G-1 flights}

A trajectory analysis by Doran et al. (2007) indicates the days when pollutants from Mexico City were likely to impact the $\mathrm{T} 1$ and T2 ground sites (Table 1). The G-1 flew nine flights with the peroxide instrument aboard, five of which were on 18, 19, 20 March with transport from Mexico City to T1 and T2. Several other days had briefer periods of flow from the urban region to these surface sites (i.e. 26 and 27 March). In some cases, the air traveling over the surface sites did not originate in the urban basin (i.e. 15 March). Also observed was a distinct change in the relative humidity on 21st March thus separating the field experiment into a dry period (1-20 March) and a wet period (21-28 March). The rate of growth of the boundary layer (BL) appeared to be similar at $\mathrm{T} 1$ and $\mathrm{T} 2$, with BL depth increasing at both sites from about $1000 \mathrm{~m}$ at 11:00 to about $3500 \mathrm{~m}$ at 15:00 LST. These depths were slightly lower than observed in a previous campaign in Mexico City (Doran et al., 1998, 2007).
The DOE G-1 Research Aircraft was based at sea level at the General Heriberto Jara International Airport in Veracruz, Mexico. Starting on 3 March 2006 through the end of the month, the DOE G-1 flew 15 research flights, and peroxide measurements were made on every flight starting on the afternoon of 15 March through 27 March. Results reported in this paper use only the data subset for this period of time. Typically, there was a morning flight track around the source region (L3, L4, L5), over the source region (L0) and sometimes downwind (L1 and L2). L0, L1 and L2 designate flight legs that passed within $3 \mathrm{~km}$ of the ground sites T0, T1 and T2, respectively (Fig. 1). Afternoon flight tracks usually included L0, L1 and L2. For a description of trace gas and particle instrumentation aboard the $\mathrm{G}-1$, the reader is directed to Springston, 2006.

\subsection{G-1 peroxide measurements}

Hydroperoxides were captured by passing sampled air over an aqueous surface film in a glass coil scrubber, followed by continuous-flow derivatization, and fluorescence detection, similar to earlier measurements (Lee et al., 1990, 1994). 
Three independent channels, using different reagents, were used to allow detection of the dissolved hydroperoxides, as summarized in Table 2. Details of the collection and analysis system can be found in the references. Due to the high altitude required for flights over Mexico City, we reconfigured the peroxide analyzer for operation in a pressurized cabin. The inlet was designed to minimize contact of sampled air with dry surfaces prior to scrubbing. Ram air was directed through a $45^{\circ}$ forward-facing $1 / 2^{\prime \prime}$ ID bypass, and drawn through $4.2^{\prime \prime}$ of $1 / 4^{\prime \prime}$ OD tubing prior to meeting scrub solution. A diaphragm pump was used to draw air at 1.5 SLPM through each channel using individual mass flow controllers. Surfaces exposed to the air sample stream were either glass or Teflon ${ }^{\circledR}$ PFA tubing. Baselines were established prior to and during flight using zero air.

Two-point calibrations were conducted before or after each flight using aqueous peroxide standards, nominally 2.0 and 4.0 or 4.0 and $8.0 \mu \mathrm{M}$, prepared from unstabilized $3 \%$ peroxide stock, with scrubbing solution used for the final dilution. Stock peroxide was titrated against standardized permanganate before and after the 30-day measurement period, and no decrease in concentration was observed. Liquid and air flow rates, nominally $0.6 \mathrm{~mL} / \mathrm{min}$ and $1.5 \mathrm{~L} / \mathrm{min}$, respectively, were calibrated regularly.

A 4-channel filter fluorimeter system with dual cadmium lamps and $24 \mu \mathrm{L}$ flow-through fluorescence cells (McPherson, Inc., Chelmsford, MA) was used for the first time in this study. The 10-90\% response time of the instrument was $42 \mathrm{~s}$. The detection limit, based on $2 \times$ the baseline noise, was $0.27 \mathrm{ppbv}$ for $\mathrm{H}_{2} \mathrm{O}_{2}$ and $0.38 \mathrm{ppbv}$ for hydroxymethyl hydroperoxide (HMHP). A leak in channel 1 prevented us from acquiring a reliable baseline for the total soluble peroxide concentration, which is needed to make the difference measurement for methyl hydroperoxide. Thus, for this study, only measurements of HMHP and $\mathrm{H}_{2} \mathrm{O}_{2}$, obtained from channels 2 and 3, are reported for the G-1 flights.

Aircraft data for the MAX-Mex field program may be obtained at the following URL: ftp://ftp.asd.bnl.gov/pub/ ASP\%20Field\%20Programs/2006MAXMex/. Unless otherwise noted, all G1 data used in this paper were 10-s averages. Times are local standard times (LST) and altitudes are mean sea level (m.s.l.) unless otherwise noted.

\subsection{T1 Ground measurements}

Hydroperoxide measurements were conducted at Tecámac University, a surface site about $35 \mathrm{~km} \mathrm{NW}$ of Mexico City at an elevation of $2.3 \mathrm{~km}$. Because the site abutted a 4-lane highway, and was located less than $1 \mathrm{~km}$ from a farm, it was impacted by motor vehicle and $\mathrm{NH}_{3}$ emissions on a regular basis. Trajectory analyses show that this site was downwind of Mexico City for approximately half of the days between 15th March and 30th March (Doran et al., 2007).
Free radicals $(\mathrm{OH}$, and the sum of peroxy radicals, $\mathrm{HO}_{2}+\mathrm{RO}_{2}$ ) were determined at this site by Chemical Ionization Mass Spectroscopy. Details of the technique are given in the reference by Sjostedt et al. (2007). Broadband ultraviolet-B (UV-B) radiation measurements were taken with Robertson-Berger radiometers (Solar Light Co. Model 501) and rain intensity was measured using a multi-sensor weather package (Vaisala, WXT150) with the RAINCAP sensor. Ozone was measured with a commercial instrument (ThermoEnvironmental Model 49).

A continuous peroxide analyzer was deployed in the Georgia Tech trailer at the surface site. We measured only total soluble hydroperoxide, using $\mathrm{pH} 9$ scrubbing solution and POHPAA-derivatizing reagent, as described above for the aircraft measurements. It is important to note that although $\mathrm{H}_{2} \mathrm{O}_{2}$ and HMHP are completely soluble under the measuring conditions, MHP is not. Since we did not determine speciated hydroperoxides at the $\mathrm{T} 1$ site, we could not correct for the lower collection efficiency of any MHP that was collected. Thus, our reported values for "total hydroperoxide" at this site should be viewed as a lower limit.

Earlier studies have shown that there is potential for substantial loss of peroxide in inlet lines during surface sampling (Jackson et al., 1996; Lee et al., 1991; Watkins et al., 1995). To avoid inlet losses, we mounted the coil scrubbers on the trailer roof approximately $5 \mathrm{~m}$ above ground, and drew air through a pinhole directly into the stripping solution. The resulting aqueous peroxide solution was pumped to the instrument through $2 \mathrm{~m}$ of $0.8 \mathrm{~mm}$ ID PFA tubing. Previous laboratory tests showed no peroxide decomposition in the aqueous solution under these conditions. However, this arrangement creates significant lag time between collecting and observing sample (12 $\mathrm{min}$ ), and a somewhat broadened response (10$90 \%$ rise time of $2.0 \mathrm{~min}$ ). Data reported here were corrected for the lag time, and ten-minute averages were used for all data analysis. The liquid flow rate was maintained nominally at $0.3 \mathrm{~mL} / \mathrm{min}$ using a peristaltic pump, and the air flow at 1 LPM using a critical orifice. Liquid and air flow rate calibrations were conducted three times during the measurement period. The local pressure at this site $(0.77$ a.t.m.) was used to compute the equivalent gas-phase concentration. Twopoint calibrations were conducted daily using aqueous peroxide standards, nominally 2.0 and $4.0 \mu \mathrm{M}$, prepared from unstabilized $3 \%$ peroxide stock, with scrubbing solution used for the final dilution. The detection limit for this configuration was $0.20 \mathrm{ppbv}$, based on twice the baseline noise. All ground data may be obtained on the NCAR data portal at the following URL: http://cdp.ucar.edu/home/home.htm. 
Table 3. Summary statistics for G-1 flights (15-27 March 2006).

\begin{tabular}{|c|c|c|c|c|c|c|c|c|c|c|c|c|}
\hline Species & L3 & & L4 & & L5 & & L0 & & L1 & & L2 & \\
\hline & Mean & Max & Mean & Max & Mean & Max & Mean & Max & Mean & Max & Mean & Max \\
\hline $\mathrm{H}_{2} \mathrm{O}_{2}$ (ppbv) & 1.2 & 2.2 & 1.1 & 2.5 & 1.6 & 3.0 & 1.4 & 2.3 & 1.3 & 2.5 & 1.4 & 3.2 \\
\hline HMHP & 0.36 & 1.1 & 0.33 & 1.3 & 0.37 & 1.0 & 0.32 & 0.8 & 0.3 & 1.2 & 0.31 & 0.77 \\
\hline $\mathrm{O}_{3}(\mathrm{ppbv})$ & 71 & 156 & 64 & 179 & 50 & 76 & 69 & 98 & 57 & 90 & 55 & 72 \\
\hline $\mathrm{NO}_{\mathrm{X}}(\mathrm{ppbv})$ & 16.4 & 50.0 & 17.7 & 85.7 & 3.3 & 41 & 23.4 & 69 & 3.3 & 10.3 & 2.3 & 6.6 \\
\hline $\mathrm{NO}_{\mathrm{y}}$ (ppbv) & 26.6 & 68 & 27.8 & 117 & 8.8 & 58 & 33.7 & 92 & 8.8 & 20 & 7.0 & 13 \\
\hline $\mathrm{NO}_{\mathrm{x}} / \mathrm{NO}_{\mathrm{y}}$ & 0.58 & 0.85 & 0.52 & 1.1 & 0.21 & 0.78 & 0.63 & 0.87 & 0.33 & 0.71 & 0.29 & 0.52 \\
\hline $\mathrm{CO}$ (ppmv) & 0.61 & 1.32 & 0.71 & 2.91 & 0.28 & 1.70 & 0.80 & 2.05 & 0.26 & 0.46 & 0.23 & 0.324 \\
\hline $\mathrm{SO}_{2}$ (ppbv) & 3.6 & 27 & 3.4 & 24 & 1.0 & 8.3 & 3.6 & 15.5 & 1.2 & 5.5 & 2.3 & 17 \\
\hline $\operatorname{PCASP}\left(10^{3} \mathrm{~cm}^{-3}\right)$ & 2.4 & 4.7 & 2.2 & 5.8 & 1.2 & 4.0 & 2.4 & 5.7 & 1.3 & 2.7 & 1.2 & 2.0 \\
\hline $\mathrm{H}_{2} \mathrm{O}\left(\mathrm{g} \mathrm{kg}^{-1}\right)$ & 6.0 & 8.8 & 6.0 & 8.5 & 5.9 & 7.9 & 5.5 & 8.0 & 5.1 & 7.9 & 4.7 & 7.5 \\
\hline $\mathrm{RH}(\%)$ & 51 & 80 & 51 & 79 & 50 & 81 & 47 & 74 & 47.2 & 83 & 43 & 83 \\
\hline Temperature $\left({ }^{\circ} \mathrm{C}\right)$ & 11.8 & 15.9 & 11.8 & 15.9 & 12.0 & 16.6 & 12.2 & 19.1 & 10.2 & 16.2 & 10.5 & 14.5 \\
\hline Altitude (km m.s.l.) & 3.24 & 4.04 & 3.43 & 4.89 & 3.44 & 4.89 & 3.02 & 3.59 & 3.61 & 4.91 & 3.68 & 4.92 \\
\hline
\end{tabular}

\section{Observations}

\subsection{G-1}

\subsubsection{General flight statistics}

In this section, we present peroxide observations from 15-27 March 2006. Shown in Fig. 1 is a composite of all the flight tracks around the source region (L3, L4, L5), over the source region (L0 over $\mathrm{T} 0$ ) and the outflow transects (L1 over T1 and L2 over T2). Listed in Table 3, according to transect, are the means and maximums for the G-1 flights. The average peroxide and HMHP concentrations, for the entire period over all the regions, were low (i.e. $\leq 1.6$ and $\leq 0.37 \mathrm{ppbv}$, respectively) with no significant increase even over T2. On the other hand, mean $\mathrm{NO}_{\mathrm{x}}$ concentrations were quite high in the source region (i.e. $\geq 23 \mathrm{ppbv}$ ) and then decreased as the air flowed over T1 and T2. From these data, it is apparent that transects L3 and L4 were actually part of the source region with average values for $\mathrm{O}_{3}, \mathrm{NO}_{\mathrm{y}}$ and $\mathrm{CO}$ similar to those of T0. Mean values of these species were significantly lower on transect L5. HMHP was observed above the detection limit in only $18 \%$ of the measurements. There was no observable trend in HMHP with altitude or geographical location. These low values are expected if the principal source of HMHP is reaction of ozone with biogenic alkenes, since abundances of the latter were rather low during the study. In Mexico City, fewer than $20 \%$ of the G-1 hydrocarbon samples showed iso- prene mixing ratios higher than $0.2 \mathrm{ppbv}$, in contrast to $36 \%$ in the Texas 2000 study and $94 \%$ in the Nashville SOS study.

\subsubsection{Vertical profiles}

Composite vertical profiles for several species of interest are shown in Fig. 2. Measurements were made upon take-off from and descent into the Veracruz Airport as well as over the Mexico City basin. Altitudes below $500 \mathrm{~m}$ are not shown due to the fact that some instruments were not turned on until the G-1 was airborne and there were concentration extremes at ground level in the airport. Altitudes lower than $2500 \mathrm{~m}$ are limited to periods when the G-1 had taken off from or was on approach to the airport at Veracruz. The $2500-3000 \mathrm{~m}$ altitude bin primarily contains data from traverses over Mexico City on L0 and surrounding areas (L3, L4, and L5). At 3000 and $3500 \mathrm{~m}$ there is a mixture of contribution from all legs except L2. At higher altitudes, above $3500 \mathrm{~m}$, most of the data are from L1 and L2. Mean $\mathrm{CO}$ and $\mathrm{NO}_{\mathrm{y}}$ concentrations were the largest between the altitudes of 2500 and $3000 \mathrm{~m}$ (i.e. over the source region). $\mathrm{Mean}_{3}$ concentrations slightly increased between the altitudes of 2500 to $4000 \mathrm{~m}$ indicating that ozone is produced as air masses move downwind over the $\mathrm{L} 1$ and $\mathrm{L} 2$ regions. Sulfur dioxide, $\mathrm{SO}_{2}$, concentrations (not shown in the figure) were dominated by the large excursions observed while flying over the Tula power plant $\left(20^{\circ} 06^{\prime} 13.23^{\prime \prime},-99^{\circ} 17^{\prime} 07.16^{\prime \prime}\right)$. After removing $\mathrm{SO}_{2}$ plume data (peak concentrations $>100 \mathrm{ppbv}$ ), we observed the highest $\mathrm{SO}_{2}$ concentrations in the MCMA region. 

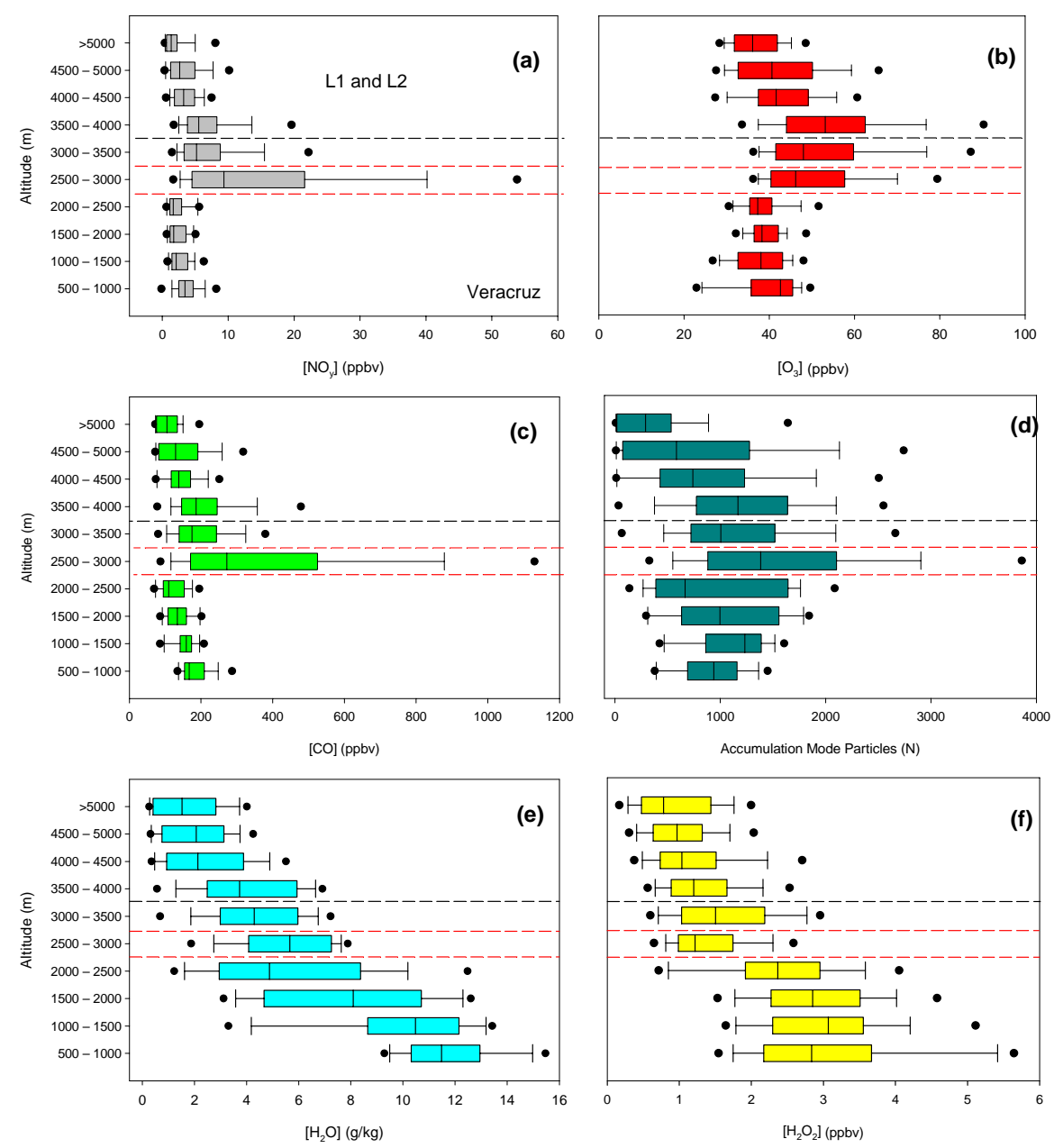

Fig. 2. Altitude profiles (m.s.l.) showing the median (thin black line in box) concentrations of important trace gases during MILAGRO. Boxes enclose $50 \%$ of the data, whiskers indicate the 10-90th percentile, and upper and lower limits (filled circles) are the 5th and 95th percentile of the data: $(\mathbf{a})=\mathrm{NO}_{\mathrm{y}},(\mathbf{b})=\mathrm{O}_{3},(\mathbf{c})=\mathrm{CO},(\mathbf{d})=$ Accumulation Mode Particles, $(\mathbf{e})=$ Water Vapor, $(\mathbf{f})=\mathrm{H}_{2} \mathrm{O}_{2}$.

Although our primary goal was to study emissions and transformations in and around the Mexico City region, we note here some interesting features from measurements conducted in and around Veracruz at altitudes $<2500 \mathrm{~m}$. The mean water vapor concentration peaked between 500 and $1000 \mathrm{~m}$ and decreased with increasing altitude (Fig. 2). Concentrations of $\mathrm{NO}_{\mathrm{y}}$ were relatively low (mean value less than 4 ppbv) and consisted of less than $20 \% \mathrm{NO}_{\mathrm{x}}$. The highest mean and maximum peroxide concentrations for the entire campaign were observed in this region. These observations are consistent with our understanding of the mechanism of $\mathrm{H}_{2} \mathrm{O}_{2}$ formation in a high-humidity and low- $\mathrm{NO}_{\mathrm{x}}$ environment.

\subsubsection{Production of peroxide}

Under conditions where $\mathrm{NO}_{\mathrm{x}}$ is low and there are no depositional losses, we expect peroxide concentration to de- pend on the production rate of radicals which is proportional to the product of $\mathrm{O}_{3}$ and $\mathrm{H}_{2} \mathrm{O}$ if, as is often the case, $\mathrm{O}_{3}$ photolysis is the dominant source of radicals (Daum et al., 1990, Tremmel et al., 1993, and Weinstein-Lloyd et al., 1996s). Figure 3 illustrates the relationship between $\mathrm{H}_{2} \mathrm{O}_{2}, \mathrm{O}_{3}$ and water vapor using all data obtained for altitudes $>3500 \mathrm{~m}$ and $\left[\mathrm{NO}_{\mathrm{y}}\right]<5 \mathrm{ppbv}$ (with the exception of ferry transects to and from Veracruz). The slope of this line $\left(0.0056 \mathrm{ppbv} / \mathrm{ppmv}^{2}\right)$ is similar to that observed in Nova Scotia $\left(0.0054 \mathrm{ppbv} / \mathrm{ppmv}^{2}\right)$, Weinstein-Lloyd et al., 1996) and over the Northeastern United States $\left(0.0050 \mathrm{ppbv} / \mathrm{ppmv}^{2}\right.$, Tremmel et al., 1993).

In a more polluted boundary layer, peroxide production is more complex, and depends on precursors, altitude and meteorology. We examined the trend in peroxide abundance when winds carried the urban plume over the L1 and L2 regions (Table 1). The best days for transport from $\mathrm{T} 0$ to $\mathrm{T} 1$ and T2 occurred on 18, 19, and 20th March. Figure 4 
shows the mean peroxide concentration as a function of location for flights on these days. During this period, the L5 transect was upwind of Mexico City and had the "cleanest" air (see Table 3). Moving downwind from L5, a decreasing trend in peroxide concentration is observed. This range is small $(0.3 \mathrm{ppbv})$ and the change in peroxide concentration is within the uncertainty of the measurement. Overall, the concentration of peroxide was low upwind of the city, and its production suppressed over the entire Mexico City basin.

\subsubsection{Peroxide in urban and power plant plumes}

During this study, we identified 63 plume traverses characterized by an ozone increase of at least $20 \mathrm{ppbv}$. Figure $5 \mathrm{a}$ shows a typical plume traverse in the Mexico City basin on 20th March. There is a $\mathrm{NO}_{\mathrm{z}}$ plume (i.e. $\mathrm{NO}_{\mathrm{z}}=\mathrm{NO}_{\mathrm{y}}-\mathrm{NO}_{\mathrm{x}}$ ) coincident with the $\mathrm{O}_{3}$ plume, but no indication of an increase in $\mathrm{H}_{2} \mathrm{O}_{2}$ above background levels. Absence of peroxide production in ozone plumes was the norm, occurring even when we encountered the highest ozone concentrations during G-1 flights - a plume containing 179 ppbv $\mathrm{O}_{3}$ and 27 ppbv $\mathrm{NO}_{\mathrm{x}}$ at 22:36 on 15th March and one containing 116 ppbv $\mathrm{O}_{3}$ and 41 ppbv $\mathrm{NO}_{\mathrm{x}}$ at 23.37 on 19th March. Peroxide formation in these plumes is inhibited by high $\mathrm{NO}_{\mathrm{x}}$ concentrations that effectively scavenge $\mathrm{HO}_{2}$ radicals. Formation of $\mathrm{NO}_{\mathrm{z}}$ but not peroxides is characteristic of $\mathrm{O}_{3}$ plumes that are formed under VOC limited conditions (Sillman, 1995; Kleinman et al., 2005b).

There were only four ozone plumes where we observed a peroxide increase above the detection limit of $0.27 \mathrm{ppbv}$. Three of these cases were observed at high ( $>4 \mathrm{~km} \mathrm{m.s.l.)}$ altitude just east of the T1 site. An example for 19th March is shown in Fig. 5b. These plumes were characterized by low $\mathrm{NO}_{\mathrm{x}}$ (in this case $<1 \mathrm{ppbv}$ ) and high $\mathrm{NO}_{\mathrm{z}}$ concentrations. These few air masses had thus aged enough to allow for production of peroxide.

The concentration of $\mathrm{H}_{2} \mathrm{O}_{2}$ during a typical traverse of the Tula power/chemical processing facility is shown in Fig. 6. High $\mathrm{SO}_{2}$ and $\mathrm{NO}_{\mathrm{y}}$ concentrations were always associated with flyovers in this region. Plumes were also characterized by dips in concentration for $\mathrm{O}_{3}$ and $\mathrm{H}_{2} \mathrm{O}_{2}$ on at least five separate flights (i.e. $\Delta \mathrm{H}_{2} \mathrm{O}_{2}=-0.6 \pm 0.1 \mathrm{ppbv}$ and $\Delta \mathrm{O}_{3}=-14$ \pm 8 ppbv) when the G-1 passed over the Tula facility. Ozone dips result from loss via reaction with NO. Cross-plume dips in peroxide were observed previously for power plants (Jobson et al., 1998; Weinstein-Lloyd et al., 1998). The net destruction of peroxide near plume center was attributed to the high $\mathrm{NO}_{\mathrm{x}}$ concentration, which inhibits peroxide production, coupled with peroxide loss by dry deposition, photolysis and reaction with $\mathrm{OH}$. The loss observed in the Tula traverses, while partly offset by production outside of the plume, is larger than can be explained by these mechanisms. There are two possibilities for the observations: loss of $\mathrm{H}_{2} \mathrm{O}_{2}$ on aerosols and artifact losses due to reaction of $\mathrm{H}_{2} \mathrm{O}_{2}$ with $\mathrm{SO}_{2}$ in the inlet. Hydrogen peroxide decomposition on aerosol

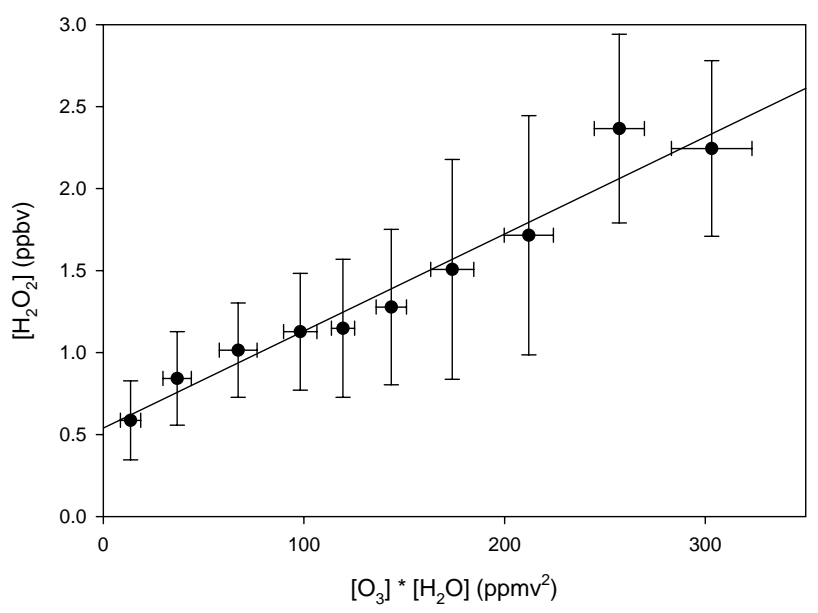

Fig. 3. Production of peroxide in the free troposphere at altitudes greater than $3500 \mathrm{~m}$ and $\left[\mathrm{NO}_{\mathrm{y}}\right]$ less than $5 \mathrm{ppbv}$ (data were binned as $10 \%$ increments of this set with circles indicating the average of the bin; error bars indicate the $1 \sigma$ standard deviation of the binned data). Slope $=0.0056, r^{2}=0.5, n=1974$.

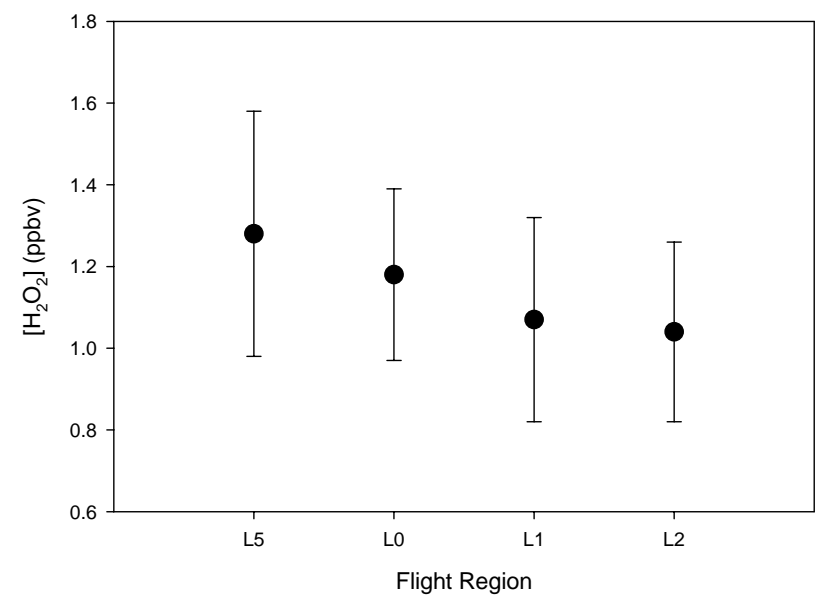

Fig. 4. Average peroxide concentration as a function of region in the Mexico City basin on southwesterly flow days. Error bars indicate the $1 \sigma$ standard deviation of the averaged data for five flights on 18 , 19, and 20th March.

surfaces may be efficient if transition metals are present. We have conducted laboratory studies that rule out artifact loss of peroxide up to an $\mathrm{SO}_{2}$ concentration of $200 \mathrm{ppb}$. However, instantaneous concentrations of $\mathrm{SO}_{2}$ may have exceeded this value in some passages through the Tula plume.

\subsubsection{Peroxide as a radical sink (i.e. $\mathrm{O}_{3}$ vs. $2 \mathrm{H}_{2} \mathrm{O}_{2}+\mathrm{NO}_{\mathrm{Z}}$ )}

Sillman has noted that the concentration of ozone, as a source of free radicals, should be related to the sum of peroxide and nitric acid, as a radical sink, independent of whether ozone formation is limited by VOC or $\mathrm{NO}_{\mathrm{x}}$ (Sillman, 1995; 


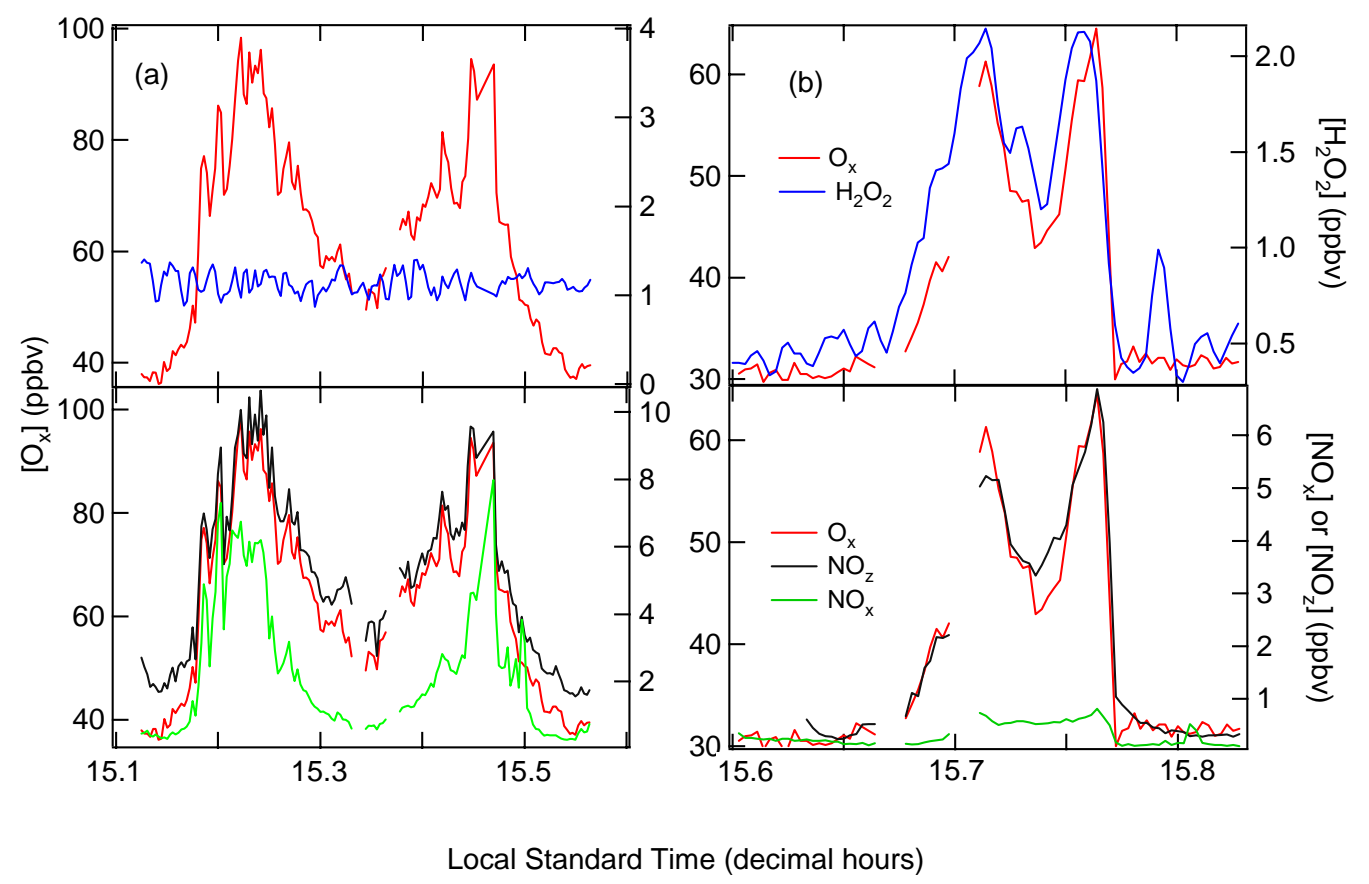

Fig. 5. Peroxide in plumes: (a) 20 March 2006, this is typical of the observations in the MCMA. Over fifty transects of ozone plumes showed no concomitant formation of peroxide, (b) 19 March 2006, 2 plumes show production of peroxide at an altitude of $4000 \mathrm{~m}$. Color scheme is the same for a and $b$ : red $=\mathrm{O}_{\mathrm{x}}$, blue $=\mathrm{H}_{2} \mathrm{O}_{2}, \mathrm{Black}=\mathrm{NO}_{\mathrm{Z}}$, Green $=\mathrm{NO}_{\mathrm{x}}$.

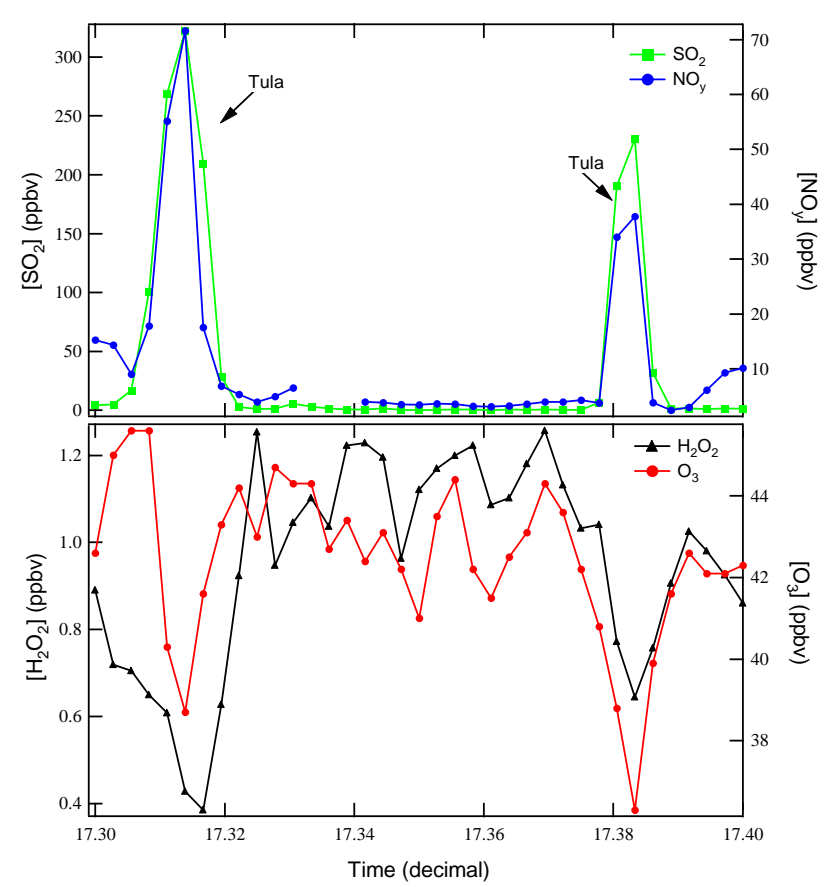

Fig. 6. Loss of ozone and hydrogen peroxide in the Tula facility stack plumes.
Sillman et al., 1998). We examined the relationship between $\mathrm{O}_{3}$ and the sum $\left(\mathrm{NO}_{\mathrm{z}}+2 \mathrm{H}_{2} \mathrm{O}_{2}\right)$ for each transect described in Sect. 2.1. We include in Table 4 only those data for which $r^{2} \geq 0.5$, indicative of a single air mass. Sillman et al. (1998) noted that there is little variation in this slope when observations are compared between rural locations and urban locations, where $\mathrm{O}_{3}$ concentrations varied from 80 to 140 ppbv. The data in Table 4 confirm this observation, as there is no observable trend in slope between the source region and downwind regions. However, we did observe a distinct difference between the dry and wet period. On 21st March, the relative humidity changed abruptly from an average $30 \%$ to over $50 \%$. After that date, the average $\mathrm{O}_{3}$ versus $\left(\mathrm{NO}_{\mathrm{z}}+2 \mathrm{H}_{2} \mathrm{O}_{2}\right)$ slope (dry vs. wet) drops by $33 \%$ from $4.8 \pm 1.4(n=12)$ to $2.9 \pm 0.8(n=7)$. The direction of change is in agreement with the assumption in Sillman's work, that the correlation arises from a relation between radical production represented by $\mathrm{O}_{3}$ and radical loss represented by $\mathrm{NO}_{\mathrm{z}}+2 \mathrm{H}_{2} \mathrm{O}_{2}$. But radical production from $\mathrm{O}_{3}$ is proportional to the product of $\mathrm{O}_{3}$ and $\mathrm{H}_{2} \mathrm{O}$, and increasing $\mathrm{H}_{2} \mathrm{O}$ will result in a lower slope if the balance between production and loss of radicals is to be maintained. It is interesting that the relations predicted by Sillman occur in Mexico City, even though $\mathrm{O}_{3}$ photolysis is not expected to be the dominant source of radicals (Volkamer et al., 2007). 
Table 4. Slope of the regression line of $\mathrm{O}_{3}$ versus its termination products $\left(2\left[\mathrm{H}_{2} \mathrm{O}_{2}\right]+\left[\mathrm{NO}_{\mathrm{Z}}\right]\right)$.

\begin{tabular}{|c|c|c|c|c|}
\hline Flight & Region & $\begin{array}{c}\text { Slope }\left[\mathrm{O}_{3}\right] / \\
\left(2\left[\mathrm{H}_{2} \mathrm{O}_{2}\right]+\left[\mathrm{NO}_{\mathrm{Z}}\right]\right)\end{array}$ & $r^{2}$ & $\mathrm{RH}(\%)$ \\
\hline \multirow[t]{2}{*}{$060315 b$} & L1 & 5.7 & 0.89 & $35 \pm 2$ \\
\hline & L3, L4, L5-L0 & 5.4 & 0.97 & $28 \pm 9$ \\
\hline \multirow[t]{2}{*}{ 060318A } & L1 & 4.0 & 0.55 & $24 \pm 10$ \\
\hline & L2 & 5.9 & 0.93 & $25 \pm 10$ \\
\hline \multirow[t]{3}{*}{$060319 a$} & L3-L1 & 3.8 & 0.80 & $38 \pm 7$ \\
\hline & L0-L1 & 4.7 & 0.53 & $36 \pm 7$ \\
\hline & $\mathrm{L} 2$ & 5.6 & 0.80 & $39 \pm 7$ \\
\hline \multirow[t]{2}{*}{$060319 b$} & L1 & 3.1 & 0.74 & $26 \pm 13$ \\
\hline & L2 & 5.0 & 0.50 & $27 \pm 9$ \\
\hline 060320a & L1 & 2.0 & 0.91 & $21 \pm 13$ \\
\hline \multirow[t]{2}{*}{$060320 b$} & L1 & 5.9 & 0.94 & $26 \pm 9$ \\
\hline & L2 & 7.0 & 0.92 & $30 \pm 9$ \\
\hline \multirow[t]{3}{*}{ 060322a } & L0 & 1.5 & 0.71 & $61 \pm 7$ \\
\hline & L1 & 2.8 & 0.57 & $54 \pm 10$ \\
\hline & L2 & 3.3 & 0.52 & $74 \pm 12$ \\
\hline \multirow[t]{2}{*}{ 060326a } & L3, L4, L5-L1 & 2.3 & 0.73 & $70 \pm 4$ \\
\hline & L0 & 3.2 & 0.87 & $72 \pm 12$ \\
\hline \multirow[t]{2}{*}{$060327 \mathrm{a}$} & L3, L4-L1 & 4.1 & 0.90 & $66 \pm 9$ \\
\hline & L0-L1 & 3.4 & 0.78 & $65 \pm 9$ \\
\hline
\end{tabular}

\subsubsection{Peroxides and particles}

Hydrogen peroxide is largely responsible for oxidizing sulfur dioxide in clouds (Penkett et al., 1979; Calvert and Stockwell, 1983; Lind et al., 1987; Kleinman and Daum, 1991; Husain et al., 2000). Model calculations predict that a large fraction of the resulting sulfate is returned to the atmosphere as aerosol when clouds evaporate (Langner and Rodhe, 1991; Benkovitz et al., 2004). Observations of aerosol growth in a boundary layer with cloud coverage also indicate the importance of sulfur dioxide and hydrogen peroxide in generating a distribution of aerosol sizes (Wang et al., 2007). Unfortunately while in Mexico, the G-1 rarely flew in or near stable clouds, so this aspect of peroxide chemistry could not be investigated. However, we have examined the potential for aerosol formation based on the stoichiometry of the one-toone reaction of $\mathrm{SO}_{2}$ and $\mathrm{H}_{2} \mathrm{O}_{2}$ in the aqueous phase.

An evaluation of the aerosol mass spectrometer measurements aboard the G-1 showed that organic and nitrate aerosols dominate in the Mexico City basin with sulfate aerosol accounting for less than $20 \%$ (Kleinman et al, 2007); in sharp contrast to the eastern United States where sulfate dominates aerosol composition (Malm et al., 2004). Be-

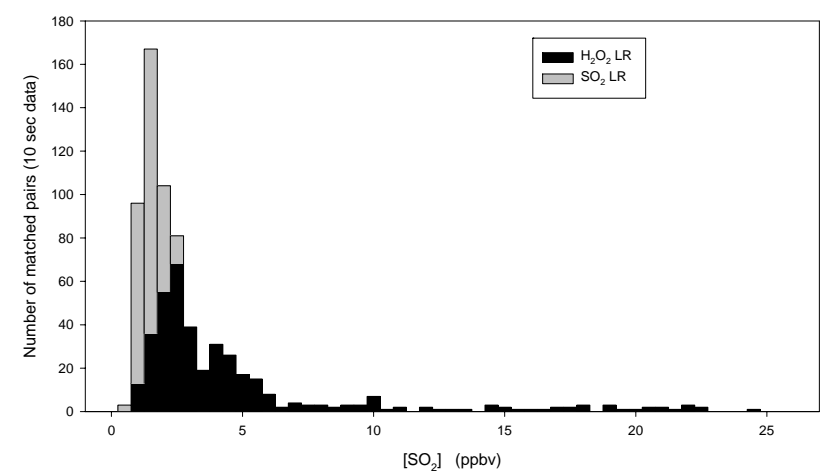

Fig. 7. Histogram of observed $\mathrm{SO}_{2}$ measurements. Highlighted bars show measurements where the $\mathrm{H}_{2} \mathrm{O}_{2}$ concentration was less than $\mathrm{SO}_{2}$. Overall, $\mathrm{H}_{2} \mathrm{O}_{2}$ is the limiting reagent (LR) for $60 \%$ of the measurements when matched with $\mathrm{SO}_{2}$ in the MCMA.

cause peroxide concentrations were suppressed throughout the Mexico City basin, it seemed unlikely that aqueous-phase oxidation of $\mathrm{SO}_{2}$ by peroxide contributed significantly to sulfate aerosol formation during the measurement period. Depending on concentration, either $\mathrm{SO}_{2}$ or $\mathrm{H}_{2} \mathrm{O}_{2}$ can be the limiting reagent to aerosol formation. In the MCMA, peroxide concentration varied from the detection limit to $3 \mathrm{ppbv}$, while $\mathrm{SO}_{2}$, leaving aside plumes from Tula, varied from the detection limit to $24 \mathrm{ppbv}$. Taken as a whole, the mean value of $\mathrm{SO}_{2}$ (3.0 ppbv) exceeded that of $\mathrm{H}_{2} \mathrm{O}_{2}$ (1.2 ppbv) making peroxide the limiting reagent for sulfate formation (i.e. if liquid were present, peroxide would have been the limiting reagent to sulfate production). More specifically, when pairs of data points are examined we find that $60 \%$ of the observations were characterized by $\mathrm{SO}_{2}$ greater than $\mathrm{H}_{2} \mathrm{O}_{2}$. In Fig. 7 , we show a histogram of this observation with the highlighted area indicating the fraction of events when the $\mathrm{H}_{2} \mathrm{O}_{2}$ concentration was less than $\mathrm{SO}_{2}$. Low humidity and a lack of available $\mathrm{H}_{2} \mathrm{O}_{2}$ thus contribute to the small fraction of sulfate in aerosol.

\subsection{Surface measurements}

3.2.1 General observations and correlations with other species

The abundance of total hydroperoxide at $\mathrm{T} 1$ was determined for the period 13th March -30th March with nighttime sampling beginning on 23rd March. We show the time course of total peroxide and related species for the entire measurement period in Fig. 8, and the composite diurnal profile of total peroxide in Fig. 9. On average, growth commences around 09:00, reaching a maximum value of $1.3 \mathrm{ppbv}$ between 14:00 and 15:00 LST. Peak peroxide values reached between 1 and 2 ppbv each afternoon, decayed slowly, and remained near 0.5 ppbv overnight. There were several episodes when we observed well-correlated plumes of peroxide and ozone after 

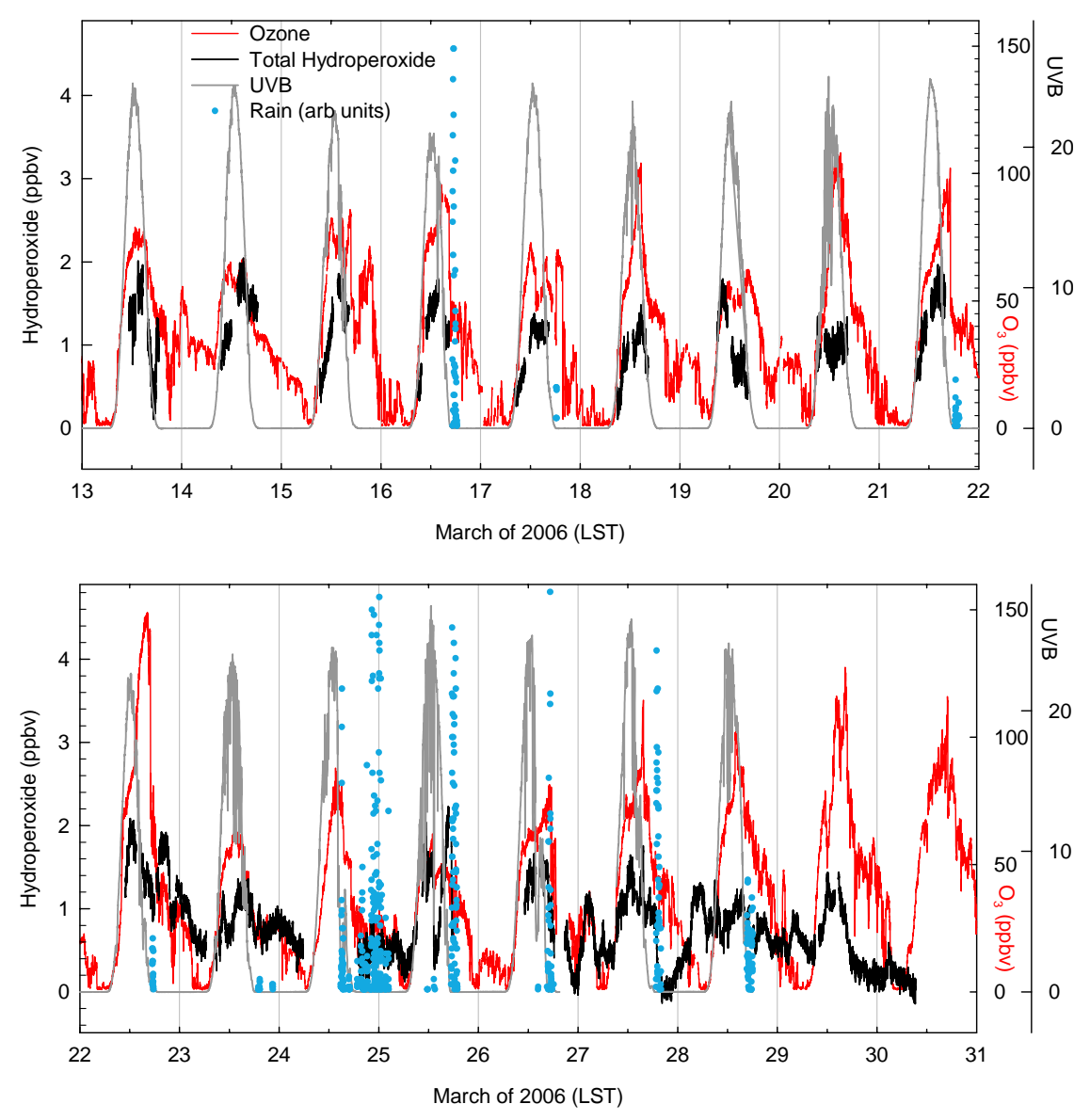

Fig. 8. Time series of total hydroperoxide (in black) for the period 13-30 March 2006 at Tecámac University. See text for peroxide species measured. Also shown are solar radiation (gray), ozone (red) and periods of measurable rainfall (blue) at this site.

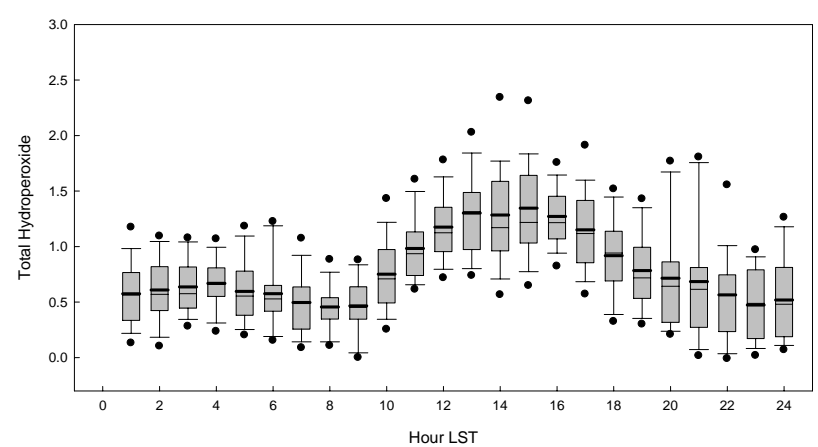

Fig. 9. Composite diurnal profile of total hydroperoxide determined at Tecámac University. Data have been binned into 1-h averages. The gray boxes enclose the central $50 \%$ of measurements; solid line is the median and dashed line is the mean; bars enclose all data in the 10th-90th percentile and symbols show the 5-95th percentile outliers.

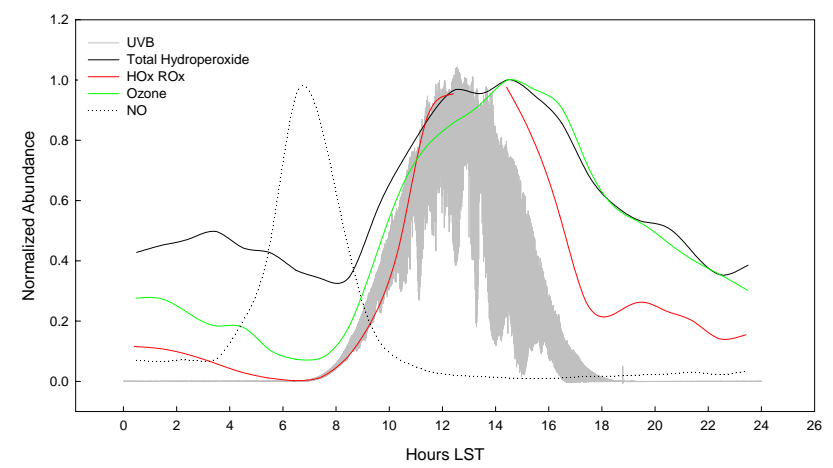

Fig. 10. Diurnal patterns for solar intensity, concentrations of total peroxide, ozone, NO, and peroxy radicals. Note that the concentrations have been scaled to illustrate the relationship between species. These are mean hourly averages, which have been normalized to better compare the diurnal variations. Average daily maximum values are 12 pptv for the sum of $\mathrm{HO}_{2}$ and $\mathrm{RO}_{2}, 80 \mathrm{ppbv}$ for $\mathrm{O}_{3}, 1.2 \mathrm{ppbv}$ for total hydroperoxide, and $80 \mathrm{ppbv}$ for NO. 

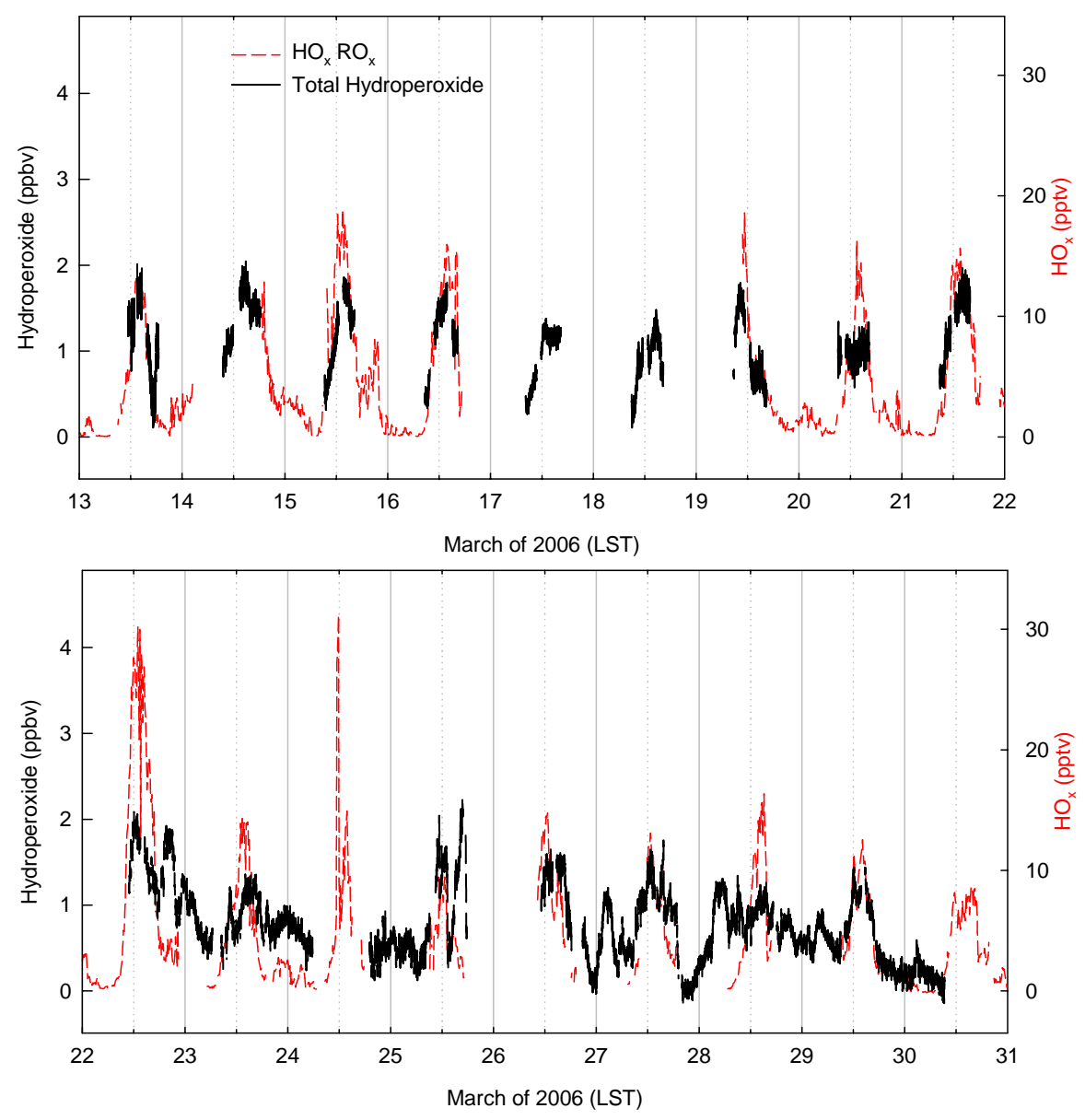

Fig. 11. Time series of hydroperoxides (black) along with the total peroxy $\left(\mathrm{HO}_{2}+\mathrm{RO}_{2}\right)$ radicals (red) at Tecámac University. See text for peroxide species measured.

midnight (see the nights of 23rd, 24th, 25th and 27th March, in Fig. 8). The timing suggests that these are due to advection events and/or boundary layer dynamics rather than local production.

\subsubsection{Peroxides and peroxide precursors}

In the absence of deposition and other losses, we would expect the abundance of peroxide to be related to solar intensity and the amount of its chemical precursors, peroxy radicals, ozone and water. Diurnal variations of these species are shown in Fig. 10. Mean ozone at this site peaks near $80 \mathrm{ppbv}$ at 15:00 LST. Ozone, UVB and peroxy radicals rise at similar rates just after 07:00 LST, with the onset of peroxide growth lagging by 20 to $40 \mathrm{~min}$. This period coincides with maximum $\mathrm{NO}_{\mathrm{x}}$ concentrations that are likely produced from local traffic emission into the shallow boundary layer. The very high concentrations of NO (the composite mean reaches $80 \mathrm{ppbv}$ at 07:00 LST) should scavenge peroxy radicals and inhibit peroxide formation. The daytime peroxide profile is consistent with local photochemical pro- duction, peaking $1-2 \mathrm{~h}$ after solar noon, as seen in other locations (Lee et al., 2000 and references therein). Ozone and total hydroperoxide persist longer than peroxy radicals once photochemistry shuts off, as expected. Peak peroxide concentrations are low: the composite mean peaks at $1.2 \mathrm{ppbv}$ at 14:00 LST. We observed low but nonzero peroxides at night, as discussed earlier. Peroxy radicals peaked near $12 \mathrm{pptv}$ at around 13:30 LST, and remained measurable throughout most of the night at $\sim 2$ pptv.

It was not uncommon to observe NO as high as hundreds of ppbv at this site, so we did not expect to see a simple correlation between peroxide and peroxy radicals. However, there were a few occasions when these species were well correlated during daytime production hours (Fig. 11). As expected, these were periods when $\mathrm{NO}_{\mathrm{x}}$ was low.

\subsubsection{Dry vs. moist regime}

As we have discussed in the aircraft observations, the measurement period was characterized by dry conditions until a rainy period began on 21st March. Rain events, indicated by 


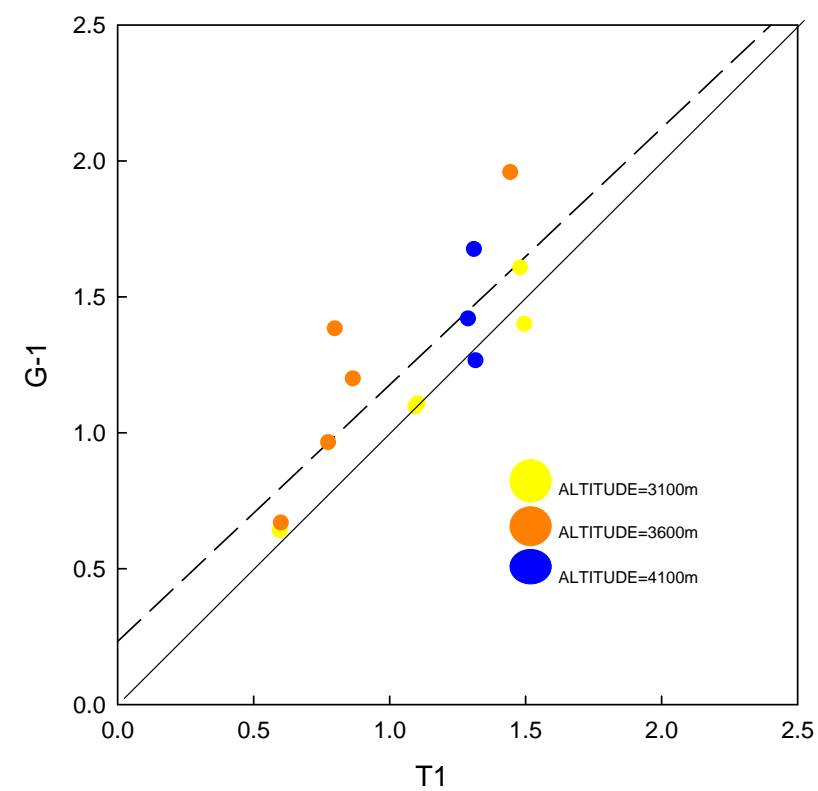

Fig. 12. Comparison of observed peroxides at the T1 surface site with the average obtained during flights over the site. The dotted line had the following regression: $y=0.94$ [Peroxide] +0.23 with a correlation coefficient $r^{2}=0.68$.

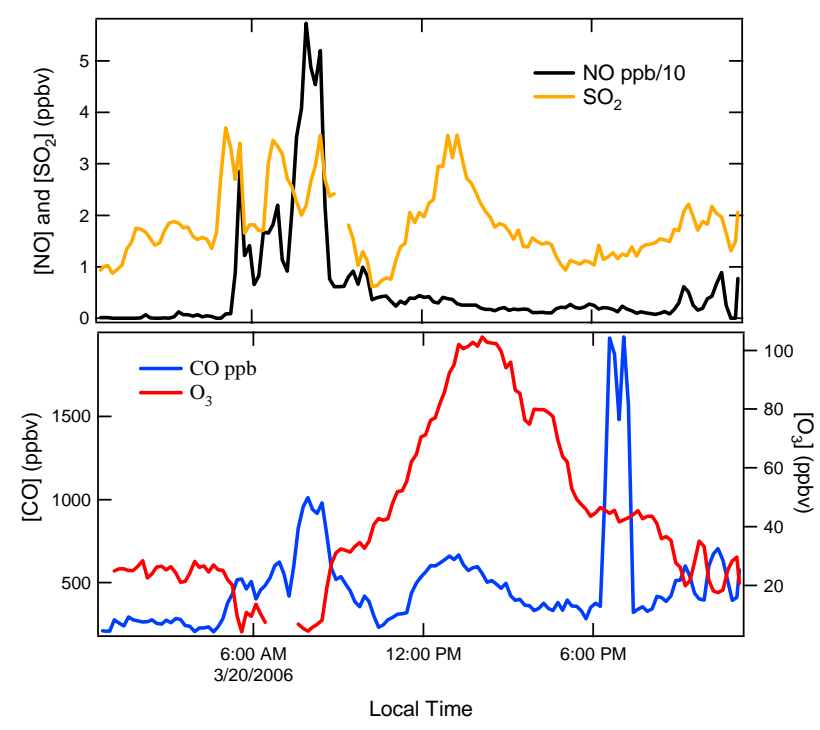

Fig. 13. Time series of trace gas observations on 20 March at T1.

the blue symbols in Fig. 8, were determined by precipitation collection on the roof of Tecámac University. Figure 8 shows that rain was rare prior to 21st March, but occurred almost daily thereafter. At the $\mathrm{T} 1$ site, median midday relative humidity increased from $12 \%$ for the dry period (13-20th March) to 26\% for the wet period (21-30th March). In addition, LIDAR showed episodes during the wet period when aerosol layers formed aloft and descended to the minimum observable height $(200 \mathrm{~m})$, possibly as rain that evaporated before reaching the surface (R. Coulter, private communication). Although the peak ozone increased from 75 ppbv (dry) to $100 \mathrm{ppbv}$ (wet), there was no significant increase in peak peroxide concentration (1.5 vs. $1.6 \mathrm{ppbv}$ ). Significant rainfall was associated with a dramatic decrease in peroxide, presumably due to wet scavenging on the afternoons of 26th March and 27th March (see Fig. 8). However, peroxides remained elevated during rainfall on the night of 25th March. Convection associated with the rain event may have mixed peroxides (and ozone) from aloft down to the surface.

\subsubsection{T0-T1-T2 transport periods}

Fast et al. (2007) and Doran et al. (2007) have identified several days in March that were most favorable for transport of pollutants from $\mathrm{T} 0$ to the $\mathrm{T} 1$ and $\mathrm{T} 2$ sampling sites. We have examined the abundance of ozone and peroxide during the days judged to be likely for transport $(18-22,24$, and 30 March) and unlikely for transport (13-16 March). Mean peak ozone is significantly higher on transport days (100 vs. $75 \mathrm{ppbv}$ ) but mean peak peroxide is essentially the same (1.7 vs. $1.6 \mathrm{ppbv})$. This is consistent with the discussion of the G-1 results, as the T1 site should experience excess ozone from high concentrations of precursors on transport days. Peroxide production does not accompany ozone formation on these days because the ozone is produced under VOC-limited conditions.

\subsection{Comparison of ground and aircraft observations}

The G-1 aircraft flew over the surface site numerous times, enabling us to compare peroxides at the $\mathrm{T} 1$ site with those observed on the aircraft. As noted in the experimental section, we were not able to measure speciated peroxides, so the comparison of $\mathrm{H}_{2} \mathrm{O}_{2}$ observations from the $\mathrm{G}-1$ with total soluble hydroperoxide at the surface site is only semiquantitative. Peroxide concentrations were compared when the G-1 was within roughly $3 \mathrm{~km}$ of $\mathrm{T} 1$ and all of these data points were taken at altitudes $<4.5 \mathrm{~km}$. There is a reasonable correlation between the concentration of total peroxide at $\mathrm{T} 1$ and $\mathrm{H}_{2} \mathrm{O}_{2}$ on G-1 over flights, as seen in Fig. 12. Concentrations observed on the G-1 were most likely higher than those observed at the surface due to deposition losses.

\section{Discussion}

In this section, we present details of the G-1 flights on 20th March as a case study. This day was selected because the standard G-1 flight tracks were optimal for observing the progression of gas-phase reactions and aerosol formation as the air moved from the source region over the surface sites. We also compare the observations with model calculations, and with hydroperoxide observations in Phoenix, AZ. 


\subsection{March 2006 - a case study}

On 20 March 2006, the winds were flowing from the southwest and had been since the previous day (shifting from the south to southwest on the previous day, 19 March). Winds were strong and steady at $\sim 6.5 \mathrm{~m} \mathrm{~s}^{-1}$ ensuring that air over $\mathrm{T} 1$ and $\mathrm{T} 2$ originated in the source region earlier in the day (i.e. not a stagnation event). The G-1 morning flight consisted of a flight track over L3, L4, and L5, and the surface sites of T0, T1 and T2. The afternoon flight track was slightly different than previous days, only going over $\mathrm{T} 1$ and T2 (i.e. no over flight of T0). Although this is not a true Lagrangian study, air sampled at $\mathrm{T} 1$ would have originated at the $\mathrm{T} 0$ site $1.5 \mathrm{~h}$ earlier in the day, as calculated with an average wind speed of $6.5 \mathrm{~m} \mathrm{~s}^{-1}$ and the $35 \mathrm{~km}$ distance between $\mathrm{T} 0$ and $\mathrm{T} 1$; the transit time from $\mathrm{T} 0$ to $\mathrm{T} 2$ was $3 \mathrm{~h}$.

Shown in Fig. 13 are the time series plots for the trace gases $\left(\mathrm{NO}, \mathrm{SO}_{2}, \mathrm{CO}\right.$, and $\left.\mathrm{O}_{3}\right)$ at the $\mathrm{T} 1$ surface site. At approximately 05:00 a.m. LST, concentrations of $\mathrm{CO}$ and $\mathrm{NO}$ increase due to local emissions into the shallow boundary layer while $\mathrm{O}_{3}$ concentrations are near zero. Later in the morning, between 10 and 11 a.m., the boundary layer begins to rise and $\mathrm{O}_{3}$ photochemistry proceeds, with $\mathrm{O}_{3}$ reaching a maximum of $100 \mathrm{ppbv}$ later in the day.

On 20th March, the G-1 flew over the T1 site 3 times, twice in the morning and once in the afternoon. That morning the average $\mathrm{O}_{3}$ concentrations observed on the G-1 as it flew over T1 were approximately 42 and $46 \mathrm{ppbv}$, in good agreement with the surface observation of 41 and $48 \mathrm{ppbv}$, respectively. By the afternoon, $\mathrm{O}_{3}$ concentrations at $\mathrm{T} 1$ had risen to $98 \mathrm{ppbv}$ and observations on the G-1 were in the same range (i.e. $\sim 90 \mathrm{ppbv}$ ). Although there was no formal comparison of the ground and aircraft instruments, the flyovers provide confidence in the validity of the measurements.

During the morning flight, concentrations of $\mathrm{CO}$ and $\mathrm{NO}_{\mathrm{x}}$ were high for the L3, L4 and L0 transects, characteristic of the source region (Fig. 14). Ozone concentrations were still low, below $50 \mathrm{ppbv}$, on transects L3, L4, L5 and L0, partly due to titration with NO. The atmosphere was quite dry in the Mexico City source region with $\mathrm{H}_{2} \mathrm{O}$ concentrations $<5 \mathrm{~g} / \mathrm{kg}$ and peroxide concentrations were also low $(\sim 1 \mathrm{ppbv})$. On the afternoon flight, shown in Fig. 15, ozone concentrations had doubled due to photochemistry and transport from the city. The peroxide concentrations had not changed significantly by the time the afternoon flight took place, indicating that there was no enhanced production in the outflow of the MCMA. However, near Veracruz, water vapor concentrations were significantly higher and $\mathrm{NO}_{\mathrm{x}}$ concentrations were low, as shown in the altitude profiles (Fig. 2), allowing for more production of peroxide with concentrations $\geq 3 \mathrm{ppbv}$.

Peroxide production rates were calculated from a constrained steady state (CSS) box model similar to that used in a study of $\mathrm{O}_{3}$ production in five US cities (Kleinman et al., 2005b). The CSS model was also used to calculate production rates of radicals and to determine the fraction of radicals
Table 5. Morning and afternoon ozone production efficiencies on 20 March 2006.

\begin{tabular}{lllll}
\hline Flight transect & $\mathrm{OPE}$ & $r^{2}$ & $\mathrm{NO}_{\mathrm{x}} / \mathrm{NO}_{\mathrm{y}}$ & $r^{2}$ \\
\hline L0 & 5.2 & 0.82 & 0.85 & 0.99 \\
L1 & 5.0 & 0.94 & 0.75 & 0.99 \\
L2 & 4.0 & 0.62 & 0.72 & 0.96 \\
\hline L1 & 6.7 & 0.98 & 0.44 & 0.94 \\
L2 & 7.4 & 0.95 & 0.25 & 0.91 \\
\hline
\end{tabular}

Notes: 1) Afternoon flights are listed after the single horizontal line; 2) For each transect, OPE is determined as the slope of a linear least squares regression of $\mathrm{O}_{3}+\mathrm{NO}_{2}$ vs. $\mathrm{NO}_{\mathrm{z}} ; \mathrm{NO}_{\mathrm{x}} / \mathrm{NO}_{\mathrm{y}}$ as the slope of $\mathrm{NO}_{\mathrm{x}}$ vs. $\mathrm{NO}_{\mathrm{y}}, r^{2}$ is the square of the correlation coefficient.

that are removed by reaction with $\mathrm{NO}_{\mathrm{x}}, \mathrm{L}_{n} / \mathrm{Q}$. For a description of the model see Kleinman et al. (2005b). In brief, observed concentrations of stable species are used to constrain fast radical chemistry. Chemical inputs consist of $\mathrm{NO}, \mathrm{CO}$, $\mathrm{CH}_{4}$ (nominal value), $\mathrm{O}_{3}, \mathrm{H}_{2} \mathrm{O}, \mathrm{H}_{2} \mathrm{O}_{2}$, organic peroxides (set equal to $\mathrm{H}_{2} \mathrm{O}_{2}$ ), $\mathrm{SO}_{2}, \mathrm{HCHO}, \mathrm{CH}_{3} \mathrm{CHO}$, and $\sim 50$ hydrocarbons measured using canister samples and by PTR-MS. Because of the difficulty in calibrating PTR-MS HCHO measurements, results were normalized using the $\mathrm{HCHO}-\mathrm{CO}-\mathrm{O}_{3}$ relations reported by Garcia et al. (2006). Photolysis rate constants were determined from an Eppley radiometer by setting up a correspondence between those measurements made in clear sky, in 3 altitude ranges as a function of time of day, and output from the TUV model (S. Madronich http: //cprm.acd.ucar.edu/Models/TUV/index.shtml). The difference between actual and clear-sky Eppley radiance measurements were used to scale the TUV photolysis rate constants, thereby providing an estimate of the effects of cloud cover and aerosols.

The observation that $\mathrm{H}_{2} \mathrm{O}_{2}$ concentrations do not increase downwind of the MCMA on 20th March is consistent with the calculations shown in Fig. 16. The calculations indicate that there was no net production (i.e. production minus loss) in the MCMA region in the morning, and thus no significant change in concentration would be observed by the time transects were flown over L1 and L2. For example, if the net production over $\mathrm{L} 0$ was in the range of -0.1 to $0 \mathrm{ppbv} \mathrm{H}_{2} \mathrm{O}_{2}$ per hour and the travel time to $\mathrm{L} 2$ was $3 \mathrm{~h}$ (at the average wind speed of $6.5 \mathrm{~m} \mathrm{~s}^{-1}$ ) then there would be no observable change in peroxide. By the afternoon, several instances of net production of $\mathrm{H}_{2} \mathrm{O}_{2} \geq 0.2 \mathrm{ppb} \mathrm{h}^{-1}$ were calculated for the $\mathrm{L} 2$ region, indicating that $\mathrm{NO}_{\mathrm{x}}$ levels had decreased and more significant formation of peroxide was beginning.

In contrast to the $\mathrm{H}_{2} \mathrm{O}_{2}$ production, significant $\mathrm{O}_{3}$ production took place between the morning flight and the afternoon flight as evidenced by the increased concentrations observed on transects L1 and L2 (i.e. $>80$ ppbv) in Fig. 15. 


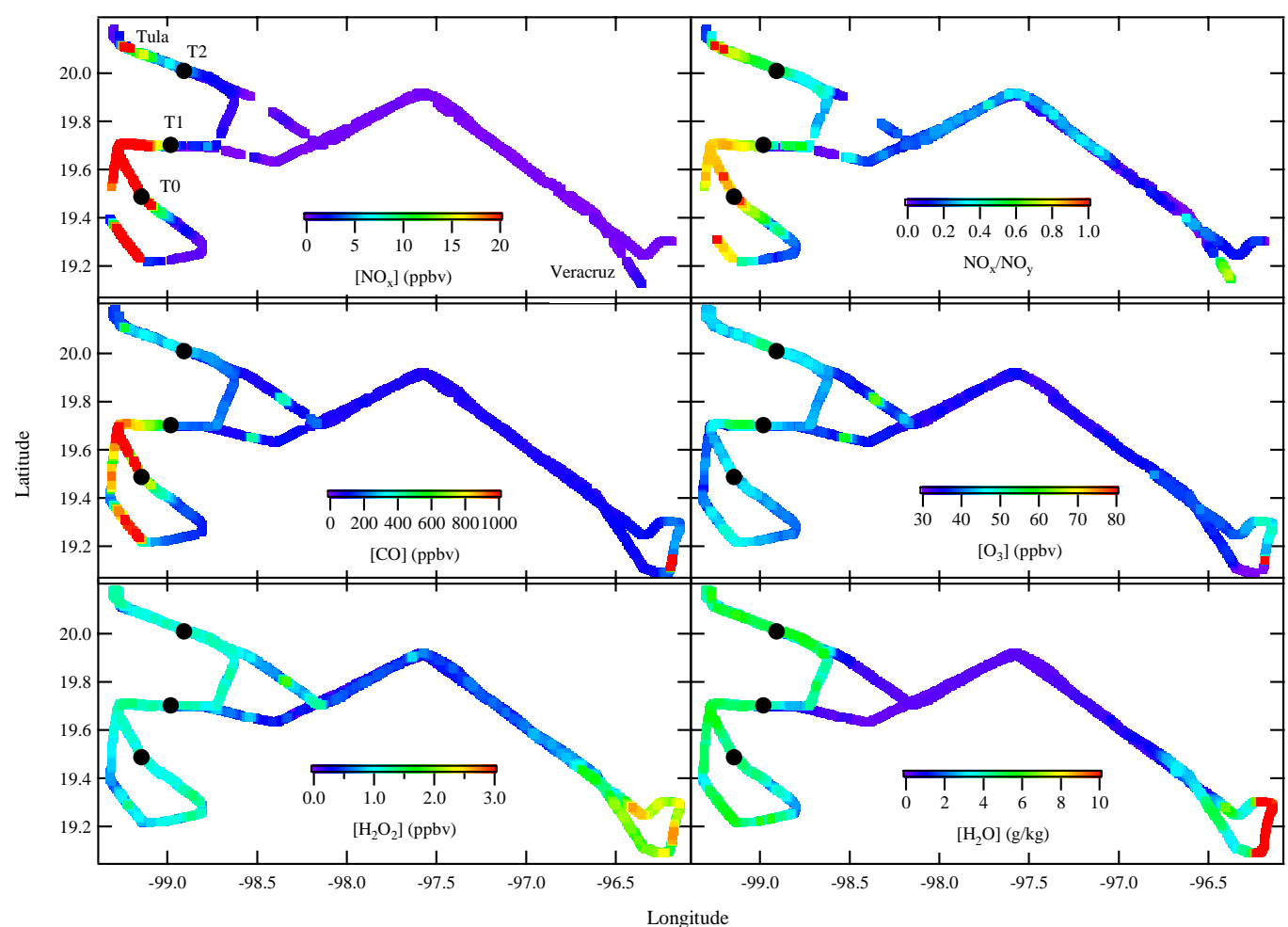

Fig. 14. Morning flight tracks on 20 March 2006. Trace gas concentrations are indicated by the color-coding on each flight track.

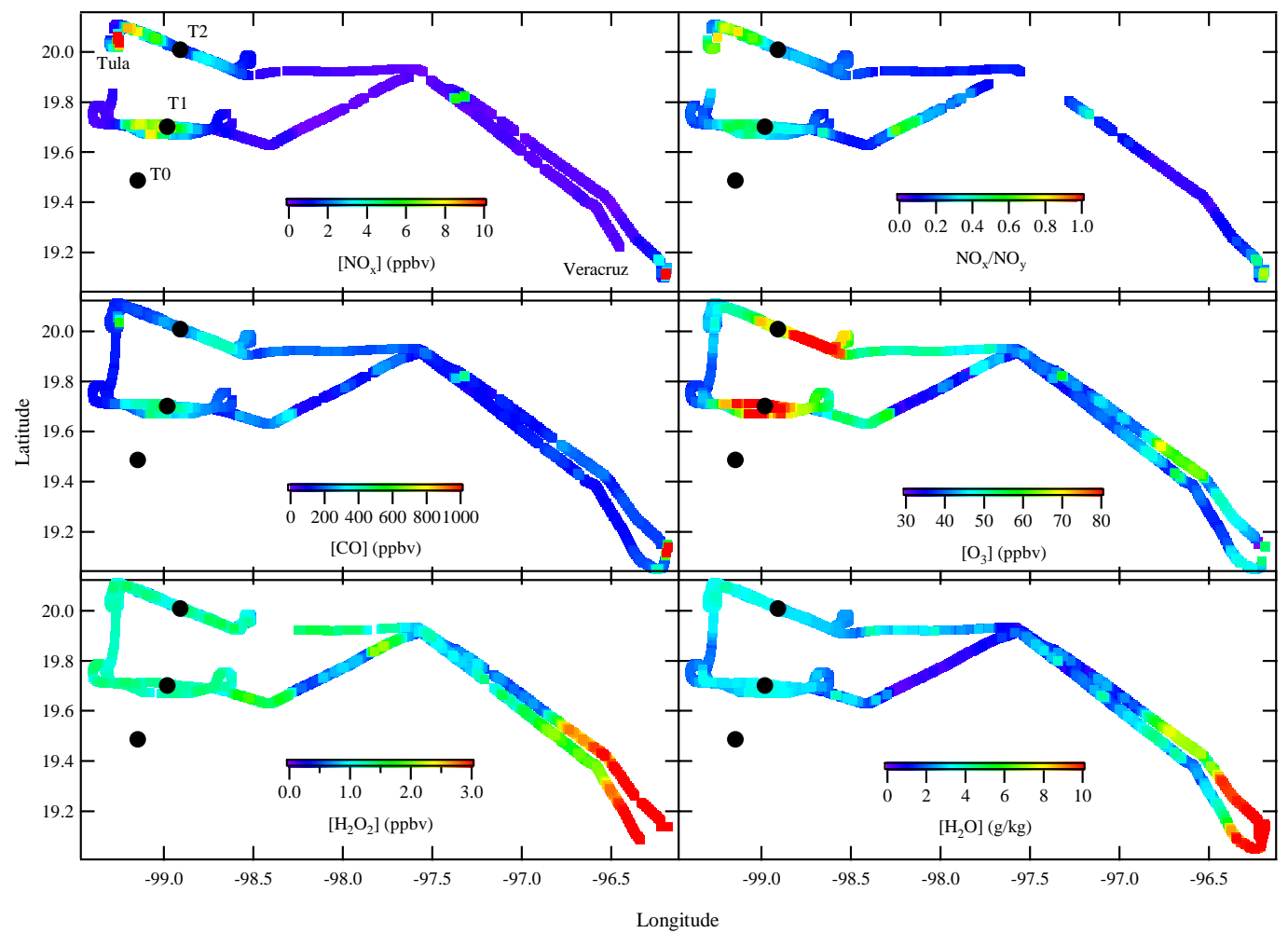

Fig. 15. Afternoon flight tracks on 20 March 2006. Trace gas concentrations are indicated by the color-coding on each flight track. 


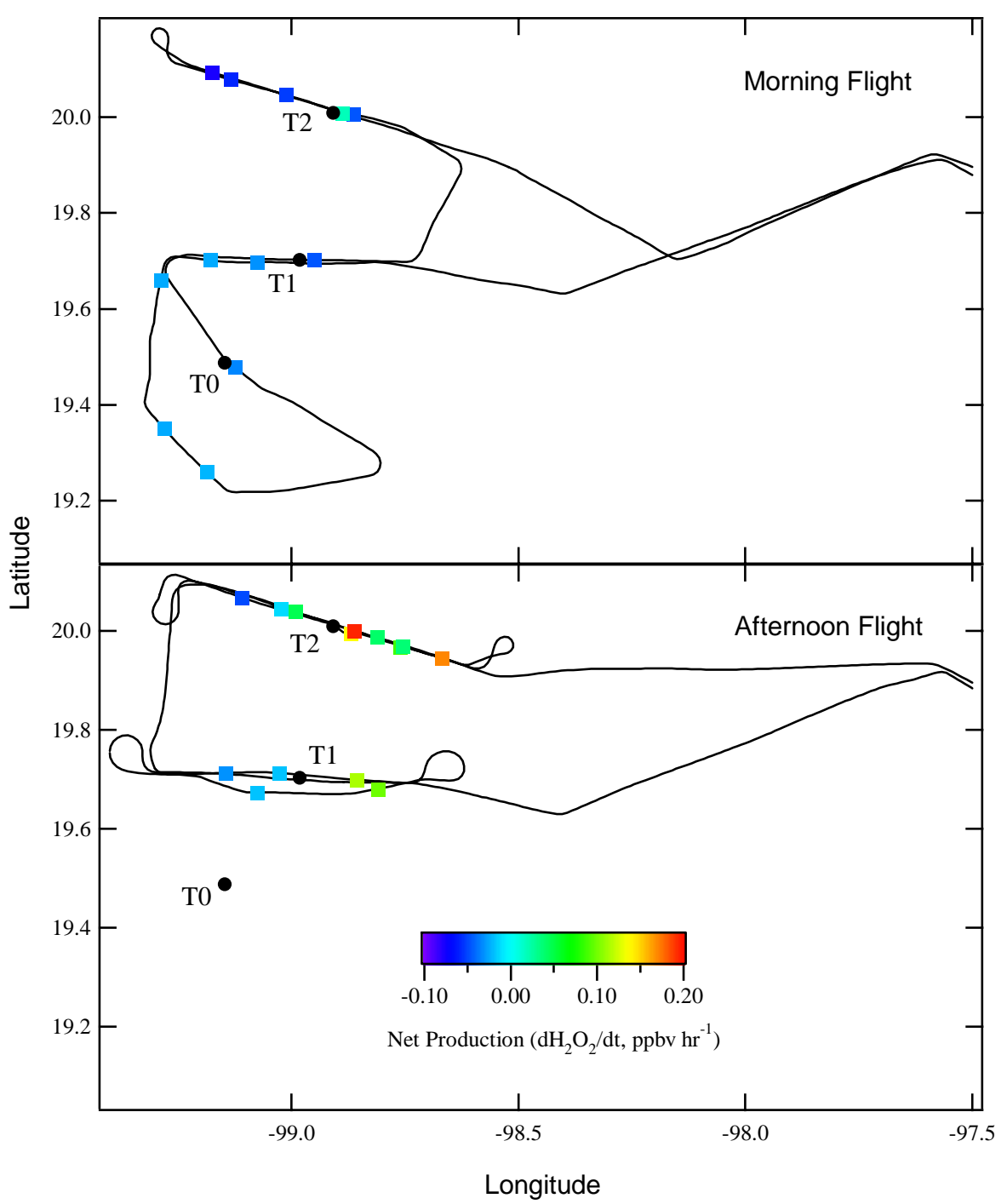

Fig. 16. Morning and afternoon net (i.e. production - loss) production rate of hydrogen peroxide (ppbv hr ${ }^{-1}$ ) on $20 \mathrm{March}^{2} 2006$ with each square indicating a hydrocarbon sampling location. Black circles indicate the location of surface sites T0, T1 and T2.

As the air mass moved from the MCMA region to the T1 and $\mathrm{T} 2$ sites, there was a significant increase in ozone production efficiency (OPE, i.e. the number of molecules of odd oxygen $=\mathrm{O}_{3}+\mathrm{NO}_{2}$ produced per molecule of $\mathrm{NO}_{\mathrm{Z}}$ ) as well as improvement in correlation between $\mathrm{O}_{\mathrm{x}}$ and $\mathrm{NO}_{\mathrm{z}}$ from the morning to afternoon flights. Ozone production efficiencies for this day and the $\mathrm{NO}_{\mathrm{x}} / \mathrm{NO}_{\mathrm{y}}$ ratios for the corresponding transects are shown in Table 5. For the morning flight, all three transects had high $\mathrm{NO}_{\mathrm{x}}$ to $\mathrm{NO}_{\mathrm{y}}$ ratios, indicative of fresh emissions due to local sources. By the afternoon flight, significant aging had taken place as the $\mathrm{NO}_{\mathrm{x}}$ to $\mathrm{NO}_{\mathrm{y}}$ ratio had decreased to 0.25 . At this point, $\mathrm{NO}_{\mathrm{x}}$ concentrations in the area had been reduced sufficiently for more peroxide production to take place (i.e. see Figs. 14, 15 and 16).

\section{2 $\mathrm{H}_{2} \mathrm{O}_{2}$ production rates by transect}

All flights were segregated into regions as described in Sect. 2.1. Median CSS values are given in Table 6. No hydrocarbon samples were taken on L5 and therefore it is not included in the table. We note that the instantaneous production rate for peroxide is low over the first 3 regions of interest and increases slightly by the time the urban air mass has moved over the L2 region. The net production of peroxide is negative on the first three legs, with positive net production on L1 and L2. For the conditions encountered, the net rate of peroxide formation was generally negative for $\mathrm{NO}_{\mathrm{x}}>$ 3 ppbv. Negative and low peroxide production rates have been observed previously in Phoenix, AZ (Nunnermacker et al., 2004) where they were attributed to the high $\mathrm{NO}_{\mathrm{x}}$ of the 
Table 6. Mean values for several CSS calculations in the Mexico City basin.

\begin{tabular}{lrrrr}
\hline & L3\&L4 & Region & L1 & L2 \\
\hline Parameter & 0.04 & 0.03 & 0.11 & 0.16 \\
$\mathrm{P}_{\text {hydrogen peroxide }}=\mathrm{H}_{2} \mathrm{O}_{2}$ production rate $_{\left(\mathrm{ppbv} \mathrm{h}^{-1}\right)}$ & -0.01 & -0.05 & 0.02 & 0.07 \\
Net $\mathrm{P}_{\text {hydrogen peroxide }}\left(\mathrm{ppbv}^{-1}\right)$ & 2.6 & 3.5 & 1.9 & 1.6 \\
$Q=$ radical production rate $\left(\mathrm{ppbv}^{-1}\right)$ & 0.35 & 0.36 & 0.33 & 0.25 \\
$\mathrm{f}\left(\mathrm{O}_{3}\right)=$ fraction of radicals produced from $\mathrm{O}_{3}$ photolysis & 16 & 28 & 16 & 11 \\
$\mathrm{P}_{\mathrm{O}_{3}}=\left(\mathrm{ppbv} \mathrm{h}^{-1}\right)$ & 0.84 & 0.88 & 0.61 & 0.45 \\
$\mathrm{~L}_{N} / Q=$ fraction of radicals removed as $\mathrm{NO}_{\mathrm{x}}$ & 22 & 15 & 35 & 30 \\
$n=$ number of calculations & & & &
\end{tabular}

Data obtained at altitudes $<4 \mathrm{~km}$ m.s.l.

source region coupled with a low rate of radical production due to the extremely dry climate. An interesting feature of our data, in agreement with Volkamer et al. (2007), is that most of the radical production is not from $\mathrm{O}_{3}$, but from photolysis of HCHO. Overall, the total radical production rate, $\mathrm{Q}$, is much higher for Mexico City than Phoenix. Therefore, the extremely high $\mathrm{NO}_{\mathrm{x}}$ concentrations effectively remove any radicals from peroxide forming pathways and inhibit peroxide formation in the Mexico City basin.

\subsection{Comparisons with calculations}

Ozone production in Mexico City has been studied using box and Eulerian chemical transport (CTM) models (e.g. Madronich, 2006; Lei et al., 2007; Tie et al., 2007). Madronich initiated a box model with an urban mixture of pollutants and followed its time evolution, finding that after one day $5 \mathrm{ppbv}$ of $\mathrm{H}_{2} \mathrm{O}_{2}$ was formed along with several hundred ppbv of $\mathrm{O}_{3}$. In a comment to this study, Madronich (2008) attributed the higher than observed oxidant levels to initializing the calculations with a $\mathrm{NO}_{\mathrm{x}}$ concentration significantly lower than observed at monitoring sites. Production of more $\mathrm{O}_{3}$ (and $\mathrm{H}_{2} \mathrm{O}_{2}$ ) at a lower $\mathrm{NO}_{\mathrm{x}}$ concentration is in agreement with an analysis of the weekdayweekend effect by Stephens et al. (2008).

Lei et al. (2007) have analyzed CTM results from 2003 in terms of radical removal pathways finding that $\mathrm{L}_{n} / \mathrm{Q}$ is close to unity, indicating VOC limited conditions and low peroxide concentrations. VOC limited conditions were substantiated by calculations with perturbed emissions rates. $\mathrm{H}_{2} \mathrm{O}_{2}$ concentrations calculated by Lei et al. (2007, and personal communication, 2008) were 1 ppbv in the Mexico City urban area; urban ozone plumes were usually associated with holes in the $\mathrm{H}_{2} \mathrm{O}_{2}$ concentration field (W. Lei, personal communication). Tie et al. (2007) also find that $\mathrm{O}_{3}$ production in the Mexico City metropolitan area is VOC limited. A concentration map for 18 March 2006 (X. Tie, personal communica- tion) shows urban $\mathrm{H}_{2} \mathrm{O}_{2}$ concentrations of $\sim 1 \mathrm{ppb}$, consistent with G-1 observations. On this day the G-1 went further west than usual, transitioning into cleaner air near $20^{\circ} \mathrm{N}, 100^{\circ} \mathrm{W}$ at which point $\mathrm{H}_{2} \mathrm{O}_{2}$ increased by $0.5 \mathrm{ppbv}$, duplicating the gradient calculated by Tie et al. (2007).

\section{Conclusions}

We have presented measurements of gas-phase hydroperoxides in and around Mexico City and Veracruz during March 2006, a region where to date there have been few field observations. Measured concentrations of hydroxymethyl hydroperoxide were at or near the detection limit for most of the program. This finding is not surprising given the near absence of biogenic alkenes (Hewitt et al., 1990). Measured concentrations of hydrogen peroxide in the Mexico City basin were generally near $1 \mathrm{ppbv}$. The high humidity and low $\mathrm{NO}_{\mathrm{x}}$ concentrations near Veracruz consistently gave rise to the highest observed peroxide concentrations during the campaign.

The G-1 data set, in and downwind of Mexico City, contained 63 transects of plumes in which $\mathrm{O}_{3}$ concentration increased by at least $20 \mathrm{ppbv}$. In only 4 of these plumes was there a significant increase in $\mathrm{H}_{2} \mathrm{O}_{2}$. The absence of $\mathrm{H}_{2} \mathrm{O}_{2}$ production indicates that $\mathrm{O}_{3}$ generally is formed under VOClimited conditions in this region.

The high $\mathrm{NO}_{\mathrm{x}}$ conditions in the Mexico City Basin resulted in a calculated low or negative net production of hydrogen peroxide, with some evidence of production on the L2 transect farthest downwind from the source region. Because peroxides can persist in the atmosphere for several days, and may serve as a reservoir for free radicals, the production of high concentrations of hydrogen peroxide in the Mexico City basin would have important regional consequences. Although we did not observe the high peroxide concentrations predicted by some models (Madronich, 2006), processed air 
at the $\mathrm{T} 2$ site displays significant ozone-forming potential, reflected by $\mathrm{NO}_{\mathrm{x}} / \mathrm{NO}_{\mathrm{y}}$ ratios near 0.3 and $\mathrm{CO}$ near 230 ppbv. Additional peroxide production in this air mass as it travels further downwind is expected. However, it would be difficult to predict its magnitude without a detailed model that includes dilution and additional precursors.

Acknowledgements. As always the authors gratefully acknowledge the pilot, co-pilot and flight crew of the DOE G-1 for another safe and successful field program. Thanks also to support and ground personnel in Veracruz, T0, T1 and at T2 for making the overall mission a success, especially Jerome Fast and colleagues for their weather forecasting and transport modeling. And special thanks to Luisa Molina and Sasha Madronich for organizing a comprehensive and successful multi-national field program. Xue $\mathrm{Xi}$ Tie at NCAR and Wenfang Lei at MIT graciously supplied us with Eulerian model predictions of $\mathrm{H}_{2} \mathrm{O}_{2}$ in Mexico City. We are grateful to Jochen Rudolf for VOC data, and to Liz Alexander and John Ortega for formaldehyde measurements by PTR-MS. Many thanks to the Atmospheric Science program within the Office of Biological and Environmental Research of DOE and to the National Science Foundation for supporting this field work and analysis: US DOE contracts DE-AC02-98CH10886 and DE-FG02-05ER63994 and NSF Grant No. ATM-0623859.

Edited by: L. Molina

\section{References}

Benkovitz, C. M., Schwartz, S., Jensen, M. P., Miller, M. A., Easter, R. C., and Bates, T. S.: Modeling atmospheric sulfur over the Northern Hemisphere during the Aerosol Characterization Experiment 2 experimental period, J. Geophys. Res., 109, D06208, doi:10.1029/2004JD004939, 2004.

Calvert, J. G. and Stockwell, W. R.: Acid generation in the troposphere by gas-phase chemistry, Environ. Sci. Technol., 17, 428A-443A, 1983.

Coulter, R.: Private communication, Environmental Sciences Division, Argonne National Laboratory, Argonne, IL, 2007.

Daum, P. H., Kleinman, L. I., Hills, A. J., Lazrus, A. L., Leslie, A. C. D., Busness, K., and Boatman, J.: Measurement and interpretation of concentrations of $\mathrm{H}_{2} \mathrm{O}_{2}$ and related species in the upper Midwest during summer, J. Geophys. Res., 95(D7), 9857-9871, 1990.

Doran, J. C., Abbott, S., Archuleta, J., et al.: The IMADA-AVER Boundary Layer Experiment in the Mexico City Area, B. Am. Meteorol. Soc., 79, 2497-2508, 1998.

Doran, J. C., Barnard, J. C., Arnott, W. P., Cary, R., Coulter, R., Fast, J. D., Kassianov, E. I., Kleinman, L., Laulainen, N. S., Martin, T., Paredes-Miranda, G., Pekour, M. S., Shaw, W. J., Smith, D. F., Springston, S. R., and Yu, X.-Y.: The T1-T2 study: evolution of aerosol properties downwind of Mexico City, Atmos. Chem. Phys., 7, 1585-1598, 2007,

http://www.atmos-chem-phys.net/7/1585/2007/.

Fast, J. D., de Foy, B., Acevedo Rosas, F., Caetano, E., Carmichael, G., Emmons, L., McKenna, D., Mena, M., Skamarock, W., Tie, X., Coulter, R. L., Barnard, J. C., Wiedinmyer, C., and Madronich, S.: A meteorological overview of the MILAGRO field campaigns, Atmos. Chem. Phys., 7, 2233-2257, 2007, http://www.atmos-chem-phys.net/7/2233/2007/.

Garcia, A. R., Volkamer, R., Molina, L. T., Molina, M. J., Samuelson, J., Mellqvist, J., Galle, B., Herndon, S. C., and Kolb, C. E.: Separation of emitted and photochemical formaldehyde in Mexico City using a statistical analysis and a new pair of gas-phase tracers, Atmos. Chem. Phys., 6, 4545-4557, 2006, http://www.atmos-chem-phys.net/6/4545/2006/.

Hewitt, C. N., Kok, G. L., and Fall, R.: Hydroperoxides in plants exposed to ozone mediate air pollution to alkene emitters, Nature, 34, 56-57, 1990.

Husain, L., Ratigan, O. V., Dutkiewicz, V., Das, M., Judd, D. C., Khan, A. R., Richter, R., Balasubramanian, R., Swami, K., and Waleck, C. J.: Case studies of the $\mathrm{SO}_{2}+\mathrm{H}_{2} \mathrm{O}_{2}$ reaction in clouds, J. Geophys. Res., 105(D8), 9831-9841, 2000.

Jackson, A. V. and Hewitt, C. N.: Hydrogen peroxide and organic hydroperoxide concentrations in air in a eucalyptus forest in central Portugal, Atmos. Environ., 30, 819-830, 1996.

Jobson, B. T., Frost, G. J., McKeen, S. A., Ryerson, T. B., Buhr, M. P., Parrish, D. D., Trainer, M., and Fehsenfeld, F. C.: Hydrogen peroxide dry deposition lifetime determined from observed loss rates in a power plant plume, J. Geophys. Res., 103, 22617 22628, 1998.

Kleinman, L. I. and Daum, P. H.: Oxidant limitation to the formation of $\mathrm{H}_{2} \mathrm{SO}_{4}$ near a $\mathrm{SO}_{2}$ source region, Atmos. Environ., Part A, 25, 2023-2028, 1991.

Kleinman, L. I., Daum, P. H., Lee, Y.-N., Nunnermacker, L. J., Springston, S. R., Weinstein-Lloyd, J., and Rudolph, J.: Sensitivity of ozone production rate to ozone precursors, Geophys. Res. Lett., 28, 15, 2903-2906, 2001.

Kleinman, L. I.: The dependence of tropospheric ozone production rate on ozone precursors, Atmos. Environ., 39, 575-586, $2005 \mathrm{a}$.

Kleinman, L. I., Daum, P. H., Lee, Y.-N., Nunnermacker, L. J., Springston, S. R., Weinstein-Lloyd, J., and Rudolph, J.: A comparative study of ozone production in 5 U.S. metropolitan areas, J. Geophys. Res., 110, D02301, doi:10.1029/2004JD005096, 2005b.

Kleinman, L. I., Springston, S. R., Daum, P. H., Lee, Y.-N., Nunnermacker, L. J., Senum, G. I., Wang, J., Weinstein-Lloyd, J., Alexander, M. L., Hubbe, J., Ortega, J., Canagaratna, M. R., and Jayne, J.: The time evolution of aerosol composition over the Mexico City plateau, Atmos. Chem. Phys., 8, 1559-1575, 2008, http://www.atmos-chem-phys.net/8/1559/2008/.

Langner, J. and Rodhe, H.: A global 3-dimensional of the tropospheric sulfur cycle, J. Atmos. Chem., 13, 225-263, 1991.

Lee, J. H., Tang, I. N., and Weinstein-Lloyd, J. B.: Nonenzymatic method for the determination of hydrogen peroxide in atmospheric samples, Anal. Chem., 62, 2381-2384, 1990.

Lee, J. H., Chen, Y., and Tang, I. N.: Heterogeneous loss of gaseous $\mathrm{H}_{2} \mathrm{O}_{2}$ in an atmospheric sampling system, Environ. Sci. Technol., 25, 339-342, 1991.

Lee, J. H., Tang, I. N., Weinstein-Lloyd, J. B., and Halper, E. B.: An improved nonenzymatic method for the determination of gasphase peroxides, Environ. Sci. Technol., 28, 1180-1185, 1994.

Lee, M., Heikes, B. G., and O'Sullivan, D. W.: Hydrogen peroxide and organic hydroperoxide in the troposphere (a review), Atmos. Environ., 34, 3475-3494, 2000.

Lei, W., de Foy, B., Zavala, M., Volkamer, R., and Molina, L. T.: Characterizing ozone production in the Mexico City 
Metropolitan Area: a case study using a chemical transport model, Atmos. Chem. Phys., 7, 1347-1366, 2007, http://www.atmos-chem-phys.net/7/1347/2007/.

Lind, J. A., Lazrus, A. L., and Kok, G. L.: Aqueous phase oxidation of sulfur (IV) by hydrogen peroxide, methyl hydroperoxide, and peroxy acetic acid, J. Geophys. Res., 92, 4171-4177, 1987.

Madronich, S.: Chemical evolution of gaseous air pollutants downwind of tropical megacities: México City case study, Atmos. Environ., 40, 6012-6018, 2006.

Madronich, S.: Interactive Comment on Atmos. Chem. Phys. Discuss., 8, 8951, 2008, Atmos. Chem. Phys. Discuss., 8, S4754S4756, 2008.

Malm, W. C., Schichtel, B. A., Pitchford, M. L., Ashbaugh, L. L., and Eldred, R. A.: Spatial and monthly trends in speciated fine particle concentration in the United States, J. Geophys. Res., 109, D03306, doi:10.1029/2003JD003739, 2004.

Molina, L. T. and Molina, M. J.: Air Quality in the Mexico Megacity: An integrated assessment, in: Alliance for Global Sustainability Bookseries, Vol. 2, edited by: Kauffman, J. M., Kluwer Academic Publishers, Boston, 384 pp., 2002.

Nunnermacker, L. J., Weinstein-Lloyd, J., Kleinman, L., Daum, P. H., Lee, Y. N., Springston, S. R., Klotz, P., Newman, L., Neuroth, G., and Hyde, P.: Ground-based and aircraft measurements of trace gases in Phoenix, Arizona (1998), Atmos. Environ., 49414956, 2004.

Penkett, S. A., Jones, B. M. R., Brice, K. A., and Eggleton, A. E. J.: The importance of atmospheric ozone and hydrogen peroxide in oxidizing sulfur dioxide in cloud and rain water, Atmos. Environ., 13, 123-137, 1979.

Qi, B., Zhang, Y. H., Chen, Z. M., Shao, K. S., Tang, X. Y., and $\mathrm{Hu}, \mathrm{M} .:$ Identification of organic peroxides in the oxidation of C1-C3 alkanes, Chemosphere, 38, 1213-1221, 1999.

Sillman, S.: Use of $\mathrm{NO}_{\mathrm{y}}, \mathrm{HCHO}, \mathrm{H}_{2} \mathrm{O}_{2}$, and $\mathrm{HNO}_{3}$ as indicators for ozone- $\mathrm{NO}_{\mathrm{x}}$-hydrocarbon sensitivity in urban locations, J. Geophys. Res., 100, 14175-14188, 1995.

Sillman, S., He, D., Pippin, M., Daum, P. H., Imre, D. G., Kleinman, L., Lee, J. H., and Weinstein-Lloyd, J.: Model correlations for ozone, reactive nitrogen and peroxides for Nashville in comparison with measurements: Implications for $\mathrm{O}_{3}-\mathrm{NO}_{\mathrm{x}}$-hydrocarbon chemistry, J. Geophys. Res., 103, 22629-22644, 1998.

Sillman, S.: The erroneous use of receptor modeling to diagnose $\mathrm{O}_{3}-\mathrm{NO}_{\mathrm{x}}$-hydrocarbon sensitivity, Atmos. Environ., 33, 22892291, 1999.

Sjostedt, S., Huey, L. G., Tanner, D. J. ,Peischl, J., Chen, G., Dibb, J. E., Lefer, B., Hutterli, M. A., Beyersdorf, A. J., Blake, N. J., Blake, D. R., Sueper, D., Ryerson, T., Burkhar, J., and Stohl, A.: Observation of hydroxyl and the sum of peroxy radicals at Summit, Greenland during summer 2003, Atmos. Environ., 41(24), doi:10.1016/j.atmosenv.2006.06.065, 2007.
Springston, S. R.: Research flights of the DOE RAF during Milagro, 2006, available at http://www.asp.bnl.gov/ASP_ST_mtg pres_2006/Poster_Springston.pdf, 2006.

Stephens, S., Madronich, S., Wu, F., Olson, J. B., Ramos, R., Retama, A., and Muñoz, R.: Weekly patterns of México City's surface concentrations of $\mathrm{CO}, \mathrm{NO}_{\mathrm{x}}, \mathrm{PM}_{10}$ and $\mathrm{O}_{3}$ during 19862007, Atmos. Chem. Phys., 8, 5313-5325, 2008, http://www.atmos-chem-phys.net/8/5313/2008/.

Tie, X., Madronich, S., Li, G., Ying, Z., Zhang, R., Garcia, A., LeeTaylor, J., and Liu, Y.: Characterizations of Chemical Oxidants in Mexico City: A Regional Chemical/dynamical Model (WRFChem) Study, Atmos. Environ., 41, 1989-2008, 2007.

Tremmel, H. G., Junkermann, W., Slemr, F., and Platt, U.: On the distribution of hydrogen peroxide in the lower troposphere over the northeastern United States during late summer 1988, J. Geophys. Res., 98(D1), 1083-1099, 1993.

Volkamer, R., Sheehy, P. M., Molina, L. T., and Molina, M. J.: Oxidative capacity of the Mexico City atmosphere - Part 1: A radical source perspective, Atmos. Chem. Phys. Discuss., 7, 53655412, 2007, http://www.atmos-chem-phys-discuss.net/7/5365/2007/.

Wang, J., Daum, P. H., Kleinman, L. I., Lee, Y.-N., Schwartz, S. E., Springston, S. R., Jonsson, H., Covert, D., and Ellemna, R.: Observation of ambient aerosol particle growth due to in-cloud processes within boundary layers, J. Geophys. Res., 12, D14207, doi:10.1029/2006JD007989, 2007.

Watkins, B. A., Parrish, D. D., Buhr, M. S., Norton, R. B., Trainer, M., Yee, J. E., and Fehsenfeld, F. C.: Factors influencing the concentration of gas-phase hydrogen peroxide during the summer in Kinterbush, Alabama, J. Geophys. Res., 100(D22), 2284122851, 1995.

Weinstein-Lloyd, J., Daum, P. H., Nunnermacker, L. J., Lee, J. H., and Kleinman, L. I.: Measurement of peroxides and related species in the 1993 North Atlantic Regional Experiment, J. Geophys. Res., 101(D22), 29081-29090, 1996.

Weinstein-Lloyd, J. B., Lee, J. H., Daum, P. H., Kleinman, L. I., Nunnermacker, L. J., Springston, S. R., and Newman, L.: Measurements of peroxides and related species during the 1995 summer intensive of the Southern Oxidants Study in Nashville, Tennessee, J. Geophys. Res., 103(D17), 22361-22373, 1998. 